\title{
Ultrapotent human antibodies protect against SARS-CoV-2 challenge via multiple mechanisms
}

\author{
M. Alejandra Tortorici, ${ }^{1 *}$, Martina Beltramello ${ }^{3 *}$, Florian A. Lempp ${ }^{4}$, Dora Pinto ${ }^{3}$, Ha V. Dang ${ }^{1}$, Laura E. \\ Rosen $^{4}$, Matthew McCallum ${ }^{1}$, John Bowen', Andrea Minola ${ }^{3}$, Stefano Jaconi ${ }^{3}$, Fabrizia Zatta ${ }^{3}$, Anna De Marco ${ }^{3}$, \\ Barbara Guarino $^{3}$, Siro Bianchi ${ }^{3}$, Elvin J. Lauron ${ }^{4}$, Heather Tucker ${ }^{4}$, Jiayi Zhou ${ }^{4}$, Alessia Peter ${ }^{3}$, Colin Havenar- \\ Daughton $^{4}$, Jason A. Wojcechowskyj ${ }^{4}$, James Brett Case ${ }^{5}$, Rita E. Chen ${ }^{5}$, Hannah Kaiser ${ }^{4}$, Martin Montiel-Ruiz ${ }^{4}$, \\ Marcel Meury ${ }^{4}$, Nadine Czudnochowski ${ }^{4}$, Roberto Spreafico ${ }^{4}$, Josh Dillen ${ }^{4}$, Cindy Ng $^{4}$, Nicole Sprugasci ${ }^{3}$, Katja \\ Culap $^{3}$, Fabio Benigni ${ }^{3}$, Rana Abdelnabi ${ }^{6}$, Shi-Yan Caroline Foo ${ }^{6}$, Michael A. Schmid ${ }^{3}$, Elisabetta Cameroni ${ }^{3}$, \\ Agostino Riva $^{7}$, Arianna Gabrielii ${ }^{7}$ Massimo Galli ${ }^{7}$, Matteo S. Pizzuto ${ }^{3}$, Johan Neyts ${ }^{6}$, Michael S. Diamond ${ }^{5}$, \\ Herbert W. Virgin ${ }^{4,8,9}$, Gyorgy Snell ${ }^{4}$, Davide Corti ${ }^{3}$, Katja Fink $^{3}+$, David Veesler ${ }^{1} \dagger$ \\ ${ }^{1}$ Department of Biochemistry, University of Washington, Seattle, WA 98195, USA. ${ }^{2}$ Institut Pasteur and CNRS UMR 3569, Unité de Virologie Structurale, Paris, France. \\ ${ }^{3}$ Humabs BioMed SA, a subsidiary of Vir Biotechnology, Bellinzona, Switzerland. ${ }^{4}$ Vir Biotechnology, San Francisco, CA 94158, USA. ${ }^{5}$ Department of Medicine, Molecular \\ Microbiology, Pathology and Immunology, Washington University School of Medicine, St. Louis, MO, USA. ${ }^{6}$ Rega Institute for Medical Research, Laboratory of Virology and \\ Chemotherapy, KU Leuven, Belgium. ${ }^{7}$ III Division of Infectious Diseases, Luigi Sacco University Hospital, University of Milan, Italy. ${ }^{8}$ Washington University School of \\ Medicine, St. Louis, MO, USA. 'UTSouthwestern Medical Center, Dallas, TX, USA. \\ *These authors contributed equally to this work. \\ †Corresponding author. Email: dveesler@uw.edu (D.V.); kfink@vir.bio (K.F.) \\ Efficient therapeutic options are needed to control the spread of SARS-CoV-2 that has caused more than \\ 922,000 fatalities as of September $13^{\text {th }}, 2020$. We report the isolation and characterization of two \\ ultrapotent SARS-CoV-2 human neutralizing antibodies (S2E12 and S2M11) that protect hamsters against \\ SARS-CoV-2 challenge. Cryo-electron microscopy structures show that S2E12 and S2M11 competitively \\ block ACE2 attachment and that S2M11 also locks the spike in a closed conformation by recognition of a \\ quaternary epitope spanning two adjacent receptor-binding domains. Cocktails including S2M11, S2E12 or \\ the previously identified S309 antibody broadly neutralize a panel of circulating SARS-CoV-2 isolates and \\ activate effector functions. Our results pave the way to implement antibody cocktails for prophylaxis or \\ therapy, circumventing or limiting the emergence of viral escape mutants.
}

Severe Acute Respiratory Syndrome Coronavirus 2 (SARSCoV-2) emerged at the end of 2019 and was sequenced by January $2020(1,2)$. Although the reservoir host responsible for spillover into the human population remains uncertain, SARS-CoV-2 appears to have originated in bats from which closely related viruses and viral sequences have been identified $(1,3)$. SARS-CoV-2 belongs to the sarbecovirus subgenus and is closely related to SARS-CoV which was responsible for an epidemic in 2002-2003 resulting in 8,098 cases and 774 fatalities worldwide $(4,5)$. The lack of pre-existing immunity to SARS-CoV-2 due to its divergence from the four circulating endemic coronaviruses, and its high human-to-human transmissibility has resulted in the ongoing COVID-19 pandemic which has already caused more than 29 million infections and over 922,000 fatalities as of mid-September 2020 .

SARS-CoV-2 infection is initiated upon attachment of the viral transmembrane spike (S) glycoprotein via a receptorbinding motif (RBM) to angiotensin-converting enzyme 2 (ACE2), leading to membrane fusion and entry into host cells (6-13). As for all coronaviruses, SARS-CoV-2 S is the main target of neutralizing antibodies (Abs) and a focus of vaccine design and therapeutic targeting efforts (14). Although vaccine development programs are fast-tracked (15-20), largescale manufacturing and administration to a large enough population for achieving community protection will likely take many months. Prophylactic and/or therapeutic anti-viral drugs could address the gap before safe and efficient vaccines become widely available and will continue to have utility in unvaccinated individuals or those who respond poorly to vaccination.

We recently described a monoclonal $\mathrm{Ab}(\mathrm{mAb})$, isolated from the memory B cells of a SARS survivor obtained 10 years after recovery, that neutralizes SARS-CoV-2 and SARS-CoV through recognition of the $\mathrm{S}$ receptor-binding domain (RBD) but without blocking ACE2 attachment (21). An optimized version of S309 is currently under evaluation in phase $2 / 3$ clinical trials. The isolation of many other RBD-targeted neutralizing Abs from COVID-19 convalescent patients (22-28) and the demonstration that they provide in vivo protection against SARS-CoV-2 challenge in small animals and non-human primates $(25,29-31)$ showed that the $\mathrm{RBD}$ is the major target of neutralizing Abs upon natural $\mathrm{CoV}$ infection. 
Clinical evaluation of therapeutic Abs directly interfering with ACE2 binding are ongoing (30-34). mAbs with exceptionally high neutralization potency, along with distinct and complementary mechanisms of action compared to existing mAbs, may enable the formulation of mAb cocktails with enhanced efficacy to control the spread of the virus and prevent resistance. Here, we assessed the possibility to combine two ultrapotent neutralizing Abs we discovered, namely S2E12 and S2M11, which exploit different mechanisms of action.

\section{Results \\ Isolation of ultrapotent SARS-CoV-2 neutralizing Abs}

To identify highly potent mAbs elicited upon SARS-CoV-2 infection, we sorted memory B cells from two individuals recovering from severe COVID-19 disease, using biotinylated prefusion SARS-CoV-2 S ectodomain trimer as bait. Two mAbs, S2E12 and S2M11, stood out for their high neutralization potency against authentic SARS-CoV-2 virus and two different SARS-CoV-2 S pseudotyped viruses (using either murine-leukemia virus (MLV) or vesicular stomatitis virus (VSV) backbones). In an assay that measures inhibition of authentic SARS-CoV-2 entry (SARS-CoV-2-Nluc (35)), we determined half-maximal inhibitory concentrations $\left(\mathrm{IC}_{50}\right)$ of 3-6 $\mathrm{ng} / \mathrm{ml}(20-40 \mathrm{pM})$ (Fig. 1, A and B). We determined $\mathrm{IC}_{50}$ values of 1.9-2.5 ng/ml for SARS-CoV-2 S-VSV (fig. S1A) and 10.3-30.4 $\mathrm{ng} / \mathrm{ml}$ for SARS-CoV-2 S-MLV (fig. S1B). In an authentic SARS-CoV-2 focus reduction neutralization test that measures inhibition of virus entry and spread (36), the $\mathrm{IC}_{50}$ values were 1.2-6.6 $\mathrm{ng} / \mathrm{ml}$ (fig. S1C). The exceptional potency of these mAbs was demonstrated further by the concentrations necessary to inhibit $90 \%$ of authentic SARS-CoV-2-Nluc viral entry $\left(\mathrm{IC}_{90}\right)$, which we determined as $26.4 \pm 7.8 \mathrm{ng} / \mathrm{mL}$ and $12.7 \pm 3.1 \mathrm{ng} / \mathrm{mL}$ for S2E12 and S2M11, respectively (Fig. 1, A and B). The higher neutralization potency of IgG compared to Fab observed for each mAb suggested that the distinct binding affinities and/or bivalent binding contribute to potency (Fig. 1, A and B). The S2E12 heavy chain uses VH1$58^{*} 01, \mathrm{D} 2-15^{*} 01$ and $\mathrm{JH} 3^{*} 02$ genes whereas S2M11 derives from VH1-2*02, D3-3*01 and JH4*02 genes. The heavy chain variable gene nucleotide sequence germline identity is $96.53 \%$ for S2M11 and $97.6 \%$ for S2E12, showing a low level of somatic hypermutation for these two mAbs.

Both S2E12 and S2M11 bound to the SARS-CoV-2 RBD and prefusion-stabilized $\mathrm{S}$ ectodomain trimer (6) but not to the SARS-CoV RBD or S (37) by ELISA (Fig. 1, C to F). Using surface plasmon resonance (SPR) and flow cytometry, we further observed that S2E12 and S2M11 compete for binding to the SARS-CoV-2 RBD or to SARS-CoV-2 S, presented either as a recombinantly expressed prefusion-stabilized $\mathrm{S}$ ectodomain trimer or as full-length S expressed at the surface of ExpiCHO cells (fig. S2, A and B). When added first, S2M11 competed in a concentration-dependent manner with the sarbecovirus neutralizing S309 mAb for binding to SARS-CoV-2 S, whereas it could bind with minimal competition when added after S309 (fig. S2B). Whereas the S2E12 Fab (or IgG) bound to SARS-CoV-2 S and RBD similarly, the binding affinity of the S2M11 Fab (or IgG) for the S trimer was enhanced relative to the isolated SARS-CoV-2 RBD (Fig. 1G and fig. S2C). Specifically, S2M11 binding kinetics to SARS-CoV-2 S were biphasic, including a first phase with identical binding kinetics and affinity as measured for binding to the isolated RBD, and a second phase with a much slower off-rate and therefore higher affinity. We observed that binding of S2M11 Fab and IgG to S was increased at $\mathrm{pH}$ 5.4, a condition that favors the closed trimer conformation, compared to $\mathrm{pH}$ 7.4 (38) (Fig. 1G, fig. S2C, and table S1). Conversely, binding of the S2E12 Fab to S was diminished at pH 5.4 (and moderately reduced for S2E12 $\mathrm{IgG})$, possibly due to the increased number of $\mathrm{S}$ trimers with closed RBDs (Fig. 1G; fig. S2, A and C; and table S1).

Collectively, these findings indicate that S2E12 and S2M11 target overlapping or partially overlapping SARS-CoV-2 RBD epitopes. The finding that S2M11 preferentially interacts with the $\mathrm{S}$ trimer relative to the $\mathrm{RBD}$ suggest that this mAb might bind to a quaternary epitope only exposed in the context of a native closed prefusion S. Finally, the enhanced binding of S2E12 to SARS-CoV-2 S in conditions favoring RBD opening (pH 7.4) indicates that this mAb might recognize a cryptic epitope not exposed in the closed $\mathrm{S}$ trimer.

\section{S2E12 potently neutralizes SARS-CoV-2 by targeting the RBM}

To understand the mechanism of S2E12-mediated potent neutralization of SARS-CoV-2, we characterized a complex between the SARS-CoV-2 S ectodomain trimer and the S2E12 Fab fragment using cryo-electron microscopy (cryoEM). 3D classification of the data showed the presence of $\mathrm{S}$ trimers with one, two or three Fabs bound to open RBDs for which we determined structures at $3.5 \AA$, $3.3 \AA$ and $3.3 \AA$ resolution, respectively (Fig. 2, A and B; fig. S3, A to G; and table S2). We subsequently used local refinement to obtain a $3.7 \AA$ map of the region corresponding to the S2E12 variable domains and $\mathrm{RBD}$, which markedly improved local resolution due to conformational dynamic relative to the rest of the $S$ trimer, and used it along with a 1.4A crystal structure of the S2E12 Fab to build a model (fig. S3, D to G, and tables S2 and S3).

S2E12 recognizes an RBD epitope overlapping with the RBM (i.e., ACE2 receptor-binding site) that is partially buried at the interface between protomers in the closed $S$ trimer (Fig. 2, A to D, and fig. S4, A and B). As a result, S2E12 can only interact with open RBDs, as is the case for ACE2 as well as for several previously described neutralizing mAbs including $\mathrm{S} 2 \mathrm{H} 14(22,25,28)$. The concave S2E12 paratope recognizes the convex RBM tip through electrostatic and van der Waals interactions (Fig. 2, C and D). Specifically, S2E12 
utilizes the heavy chain complementary determining regions (CDR) 1-3 and the light chain CDR1 and CDR3, respectively accounting for $2 / 3$ and $1 / 3$ of the paratope buried surface area, to recognize residues $455-458$ and $473-493$ of the SARSCoV-2 RBD (Fig. 2, C and D). Virtually all the S2E12 contacts with the RBD are mediated by germline encoded residues with only 1 out of 5 heavy chain (G109) and 1 out of 4 light chain (G94) mutated residues contributing to the paratope. The structural data explain that S2E12 binds efficiently to both the RBD and the prefusion $\mathrm{S}$ trimer (Fig. 1G) and potently neutralizes SARS-CoV-2 (Fig. 1, A and B, and fig. S1, A and C): (i) S2E12 recognizes a tertiary 3D epitope, i.e., an epitope that is fully contained within one $\mathrm{S}$ protomer; (ii) $\sim 50 \%$ of $\mathrm{S}$ trimers naturally harbor one open RBD at the viral surface or in recombinantly expressed $\mathrm{S}$ ectodomain trimers as observed by cryo-electron tomography and single particle cryoEM, respectively $(6,39)$, and (iii) S2E12 binding shifts the RBD conformational equilibrium toward open $\mathrm{S}$ trimers, as previously described for RBM-targeted mAbs $(22,28,37)$.

\section{S2M11 locks the SARS-CoV-2 S trimer in the closed state through binding to a quaternary epitope}

We carried out cryoEM analysis of S2M11 in complex with SARS-CoV-2 $S$ to elucidate the molecular basis of its preferential recognition of the $\mathrm{S}$ trimer compared to the RBD and its mechanism of neutralization. 3D classification of the cryoEM data revealed the exclusive presence of $\mathrm{S}$ trimers adopting a closed conformation, which allowed us to determine a $2.6 \AA$ structure of SARS-CoV-2 S bound to three S2M11 Fab fragments (Fig. 3, A and B; fig. S5, A to F; and table S2). S2M11 recognizes a quaternary epitope through electrostatic interactions and shape complementarity, comprising distinct regions of two neighboring RBDs within an S trimer (Fig. 3, C and D). Specifically, S2M11 CDRH1, CDRH2 and the heavy chain framework region 3 (FR3) are docked into the RBM crevice (burying a surface of $\sim 400 \AA^{2}$ ) whereas CDRH3 spans the interface between the RBM and helices 339-343, 367-374 as well as residue 436 of an adjacent RBD belonging to the neighboring protomer (i.e., burying a total surface of $\sim 500 \AA^{2}$ ) (Fig. 3, C and F). Although most interactions are mediated by the S2M11 heavy chain, CDRL2 interacts with residues 440441 and CDRL1 forms key contacts with the glycan at position $\mathrm{N} 343$, which is rotated $\sim 45^{\circ}$ compared to the orientation it adopts in the S309-bound S structure (21), both sets of interactions occurring with the neighboring RBD (quaternary epitope) (Fig. 3, C and F, and fig. S5G). Three out of eight S2M11 heavy chain residues that are mutated relative to germline contribute to epitope recognition (Ile54, Thr77 and Phe102) whereas none of the two light chain mutated residues participate in RBD binding.

The observation that all particle images correspond to closed S trimers when bound to S2M11 contrasts with our previous finding of $\sim 50 \% / 50 \%$ of trimers closed or with one RBD open in the absence of bound mAb (6) or in complex with S309 (21) or S2H13 (28), which do not select for any specific RBD conformation. Based on these data, we conclude that S2M11 stabilizes the closed conformation of the S trimer by interacting with a composite epitope including two neighboring RBDs (from two distinct protomers) that are close to each other in the closed state but spread apart upon RBD opening (6) (fig. S4, C and D). These results also explain the enhanced S2M11 binding affinity for S compared to the RBD (Fig. 1G), as only the S trimer enables binding to the quaternary epitope which buries a $\sim 60 \%$ greater paratope surface area compared to binding to the isolated RBM (Fig. 3, A to F). We therefore interpret the biphasic binding as S2M11 interacting with a tertiary epitope present in open RBDs (fast offrate), based on the identical kinetics and affinity measured relative to isolated $\mathrm{RBD}$, and S2M11 recognizing its full quaternary epitope (slow off-rate).

\section{S2M11 and S2E12 inhibit SARS-CoV-2 attachment to ACE2 and trigger Fc-mediated effector functions}

The structural data indicate that both S2E12 and S2M11 would compete with ACE2 attachment to the RBD as they recognize epitopes overlapping with the RBM (Fig. 4, A and B). Moreover, S2M11-induced stabilization of SARS-CoV-2 S in the closed conformational state yields $S$ trimers with masked RBMs that are incompetent for receptor engagement, as previously shown for an engineered $\mathrm{S}$ construct covalently stabilized in the closed state (40). Hence, both S2E12 and S2M11 blocked binding of SARS-CoV-2 S or RBD to immobilized human recombinant ACE2 measured by biolayer interferometry (Fig. 4, C and D). Additionally, both S2E12 and S2M11 inhibited binding of ACE2 to SARS-CoV-2 S expressed at the surface of $\mathrm{CHO}$ cells (Fig. $4 \mathrm{E}$ ), validating this mechanism of neutralization using full-length native $S$ trimers. The comparable efficiency of S2E12 and S2M11 to block S attachment to ACE2 correlates with their similar neutralization potencies.

To further investigate the mechanism of SARS-CoV-2 inhibition by S2E12 and S2M11, we performed a cell-cell fusion assay using VeroE6 cells (which endogenously express ACE2 at their surface) transiently transfected with full-length wildtype SARS-CoV-2 S. Although S2E12 and S2M11 bind and stabilize different conformations of the $\mathrm{S}$ protein, both $\mathrm{mAbs}$ efficiently blocked syncytia formation (Fig. 4F), which results from S-mediated membrane fusion. The absence of syncytia formation likely is explained by S2E12- or S2M11-mediated disruption of ACE2 binding along with S2M11-induced inhibition of membrane fusion through conformational trapping of SARS-CoV-2 S in the closed state.

Ab-dependent cell cytotoxicity (ADCC) mediated by natural killer cells or Ab-dependent cell phagocytosis (ADCP) 
mediated by macrophages or monocytes are Fc-mediated effector functions that can contribute to protection by facilitating virus clearance and by supporting immune responses in vivo, independently of direct neutralization (41). As a prerequisite for ADCC to occur, we validated that infected cells express SARS-CoV-2 S on their surface (fig. S6, A and B). To evaluate the ability of S2M11 and S2E12 to leverage ADCC and $\mathrm{ADCP}$, we tested if these mAbs (IgG1 backbone) could induce $\mathrm{Fc} \gamma$ RIIa and Fc $\curlyvee$ RIIIa-mediated signaling using a luciferase reporter assay. S2M11 promoted efficient, dose-dependent Fc $\curlyvee$ RIIIa-mediated (but not Fc $\curlyvee$ RIIa-mediated) signaling, in particular for the high affinity (V158) variant of the Fc receptor, to levels comparable to the cross-reactive mAb S309 (Fig. $4 \mathrm{G}$ and fig. S6, C and D) (21). In contrast, S2E12 triggered Fc $\curlyvee$ RIIa-mediated (but not Fc $\curlyvee$ RIIIa-mediated) signaling, possibly as a result of the distinct orientation of the mAb relative to the membrane of the effector cells in comparison to S2M11 and S309 (Fig. 4G and fig. S6C). Accordingly, S2M11 but not S2E12 showed Fc $\gamma$ RIIIa-dependent ADCC activity (Fig. 4H and fig. S6E) and ADCP activity (Fig. 4I). As we observed efficient activation of effector functions when mixing S2M11 with S2E12 or S309 (Fig. 4, G and H, and fig. S6E), we propose that cocktails of these mAbs can leverage additional protective mechanisms in vivo besides inhibition of viral entry.

\section{Formulation of ultrapotent neutralizing Ab cocktails against SARS-COV-2}

Surveillance efforts have led to the identification of a number of S mutants among circulating SARS-CoV-2 isolates. Several naturally occurring RBD mutations were shown to abrogate interactions with known mAbs and to reduce immune sera binding, raising concerns that viral neutralization escape mutants could emerge or be selected under pressure from mAbbased anti-viral treatments (42). To investigate if S2E12- and S2M11-mediated neutralization might be affected by SARSCoV-2 polymorphism, we tested binding of either mAb to 29 $\mathrm{S}$ protein variants (corresponding to mutations detected in circulating SARS-CoV-2 isolates) expressed at the surface of CHO cells. The Y449N, E484K/Q, F490L and S494P RBD variants led to decreased S2M11 binding to $S$ whereas none of the mutants tested affected interactions with S2E12, although several of them are found in the epitope of this latter $\mathrm{mAb}$ (table S4). The impact of these substitutions on S2M11 binding is explained by the structural data showing that the SARSCoV-2 S Y449 and E484 side chains are hydrogen-bonded to the S2M11 heavy chain F29 backbone amide and the N52/S55 side chains, respectively, and the F490 and S494 residues are buried at the interface with S2M11. SARS-CoV-2 S-VSV pseudotyped virus entry assays with selected $S$ variants confirmed these results and showed that the Y449N, E484K/Q, F490L/S and S494P individual substitutions abrogated
S2M11-mediated neutralization whereas the $\mathrm{L} 455 \mathrm{~F}$ variant reduced neutralization potency by an order of magnitude (fig. S7, A, C, and E). S2E12 neutralized efficiently all variants tested except G476S that showed an order of magnitude decreased potency (fig. S7, B, D, and F). In agreement with deep mutational scanning data (43), we found that the $Y 449 \mathrm{~N}$ variant was impaired in its ability to bind ACE2 (fig. S8) which is expected to reduce viral fitness, likely explaining that this mutation has been reported to date in only one out of 90,287 complete SARS-CoV-2 genome sequences. Although rare, the G476S, E484K/Q, S494P and F490L/S mutations have been detected in 20,10/17, 15 and 5/8 viral isolates and in theory could be selected under the selective pressure of S2E12 or S2M11. Overall, fifteen SARS-CoV-2 S variants with a single amino acid substitution within the S2M11 epitope were reported, with a prevalence of less than $0.1 \%$ as of September 2020 (fig. S7G).

To circumvent the risk of emergence or selection of neutralization escape mutants, we assessed whether S2M11, S2E12 and S309 could be combined in two-component mAb cocktails based on their complementary mechanisms of action. SARS-CoV-2 S-VSV pseudotyped virus entry assays showed that mAb cocktails potently neutralized the $Y 449 \mathrm{~N}$, S494P and G476S variants and overcame the neutralization escape phenotype observed with single mAbs (fig. S7, H to J). A concentration matrix of S2E12 and S2M11 revealed their additive neutralization effects without antagonism, despite the fact that both Abs compete for binding to the RBM (fig. S9, A to C). Moreover, the combination of S309 with S2E12, which do not compete for binding to S, and S309 and S2M11, which partially compete (i.e., for attachment to the closed $S$ trimer), also yielded additive neutralization effects (fig. S9, D to F), suggesting that two- (or three-) component mAb cocktails are a promising therapeutic strategy to prevent the emergence or the selection of viral mutants escaping mAb therapy.

\section{S2M11 and S2E12 protect hamsters against SARS-CoV- 2 challenge}

To evaluate the protective efficacy of S2E12 and S2M11 against SARS-CoV-2 challenge in vivo, either mAb or a cocktail of both mAbs were tested in a Syrian hamster model (44). The mAbs were engineered with heavy and light chain constant regions from Syrian hamster IgG2 to allow optimal triggering of Fc-dependent effector functions. mAbs were administered via intraperitoneal injection $48 \mathrm{~h}$ before intranasal challenge with $2 \times 10^{6}$ TCID $_{50}$ of SARS-CoV-2. Four days later, lungs were collected for the quantification of viral RNA and infectious virus. Either mAb alone or cocktails with $0.5 \mathrm{mg} / \mathrm{kg}$ or $1 \mathrm{mg} / \mathrm{kg}$ total $\mathrm{mAb}$ decreased the amount of viral RNA detected in the lungs by 2 to 5 orders of magnitude compared to hamsters receiving a control mAb (Fig. 5A). The amounts of viral RNA detected at day 4 inversely correlated 
with serum mAb concentration measured at the time of infection (Spearman R -0.574, p=0.0052) (Fig. 5B). Prophylactic administration of these mAbs at all doses tested completely abrogated viral replication in the lungs, with the exception of a single animal which received the low dose cocktail and was partially protected (Fig. 5C). These data show a remarkable protective efficacy of both mAbs at low doses, individually or as cocktails, in line with their ultrapotent in vitro neutralization.

\section{Discussion}

S2M11 and S2E12 were identified among almost 800 screened Abs isolated from 12 individuals who recovered from COVID19. The ultrapotency and quaternary epitope of S2M11 appear to be rare compared to more canonical RBM-specific neutralizing Abs, as the latter type of mAbs were present in every donor we analyzed. A mAb recognizing the closed $\mathrm{S}$ conformation (mAb 2-43) was previously identified and low resolution mapping of its binding site suggested it might interact with a quaternary epitope which appears distinct from that of S2M11 (45). Two recent reports describe the identification of a mAb and of a nanobody targeting quaternary epitopes, spanning two neighboring RBDs, which are present in the closed $\mathrm{S}$ trimer. $\mathrm{Nb} 6$ was identified from a naïve nanobody library, affinity matured and trimerized to achieve an $\mathrm{IC}_{50}$ of $160 \mathrm{pM}$, however without the ability to exert effector functions (46). C144 was isolated from a COVID-19 convalescent serum sample, uses VH3-53 and VL2-14 genes, harbors a 25residue long CDRH3 and potently neutralizes SARS-CoV-2 (47). Similar to S2M11, Nb6 (along with its engineered derivatives) and $\mathrm{C} 144$ use $\mathrm{CDR}(\mathrm{H}) 3$ to bridge two neighboring RBDs and stabilize SARS-CoV-2 $\mathrm{S}$ in the closed state. A long CDRH3 of 15 or more amino acid residues was a common feature of C144-type mAbs (47). Contrary to the C144 25-residue long CDRH3, S2M11 achieves this bridging with a relatively short CDRH3 of 18 amino acids (IMGT definition (48)). As a result, all three binders inhibit SARS-CoV-2 through interfering with ACE2 attachment to $S$ through direct competition and locking of the $\mathrm{S}$ trimer in the closed state. mAbs recognizing viral surface glycoproteins by binding to quaternary epitopes have been identified against Epstein-Bar virus (49), Dengue virus (50-53), Zika virus (54) Ebola virus (55), West Nile virus (56) and HIV (57) and proved to be exceptionally potent or broad. S2M11, along with $\mathrm{Nb} 6$ and C144, therefore defines a distinct class of potent neutralizers of SARS-CoV-2 relative to previously isolated mAbs.

We recently described that the magnitude of $A b$ responses to SARS-CoV-2 $\mathrm{S}$ and nucleoprotein and neutralizing $\mathrm{Ab}$ titers correlate with clinical scores (28). The SARS-CoV-2 RBD is the main target of potent neutralizing S-specific Abs in COVID-19 patient sera or plasma samples, thereby focusing most of the selective pressure imposed by the humoral immune response on this domain $(23,28)$. Given that several RBD variants have been found among circulating SARS-CoV2 isolates, combining RBD-specific mAbs with different binding modes and distinct mechanisms of neutralization could prove essential for successful clinical application. A combination of S2M11 and S2E12 or cocktails of either of these mAbs with S309 yielded additive effects on neutralization potency. Moreover, Ab cocktails comprising S309 and/or S2M11 demonstrated robust activation of ADCC and ADCP, suggesting that combining these mAbs using distinct neutralization mechanisms would trigger these protective mechanisms in vivo. S2E12 and S2M11 (harboring a hamster Fc), individually or formulated as cocktails, conferred significant protection using $\mathrm{mAb}$ doses that are, to our knowledge, the lowest reported for human mAbs tested in hamster models. As a result, the $\mathrm{mAb}$ cocktails characterized here are expected to take advantage of both ultrapotent neutralization, different mechanisms of action and Fc-mediated effector functions to protect from a broad spectrum of circulating SARS-CoV-2 isolates and limit the emergence of neutralization escape mutants. We propose that combinations of mAbs leveraging multiple distinct mechanisms of action with additive or synergistic effects could provide additional benefits for clinical application.

\section{REFERENCES AND NOTES}

1. P. Zhou, X.-L. Yang, X.-G. Wang, B. Hu, L. Zhang, W. Zhang, H.-R. Si, Y. Zhu, B. Li, C.L. Huang, H.-D. Chen, J. Chen, Y. Luo, H. Guo, R.-D. Jiang, M.-Q. Liu, Y. Chen, X.-R. Shen, X. Wang, X.-S. Zheng, K. Zhao, Q.-J. Chen, F. Deng, L.-L. Liu, B. Yan, F.-X. Zhan, Y.-Y. Wang, G.-F. Xiao, Z.-L. Shi, A pneumonia outbreak associated with a new coronavirus of probable bat origin. Nature 579, 270-273 (2020). doi:10.1038/s41586-020-2012-7 Medline

2. N. Zhu, D. Zhang, W. Wang, X. Li, B. Yang, J. Song, X. Zhao, B. Huang, W. Shi, R. Lu, P. Niu, F. Zhan, X. Ma, D. Wang, W. Xu, G. Wu, G. F. Gao, W. Tan; China Novel Coronavirus Investigating and Research Team, A Novel Coronavirus from Patients with Pneumonia in China, 2019. N. Engl. J. Med. 382, 727-733 (2020). doi:10.1056/NEJMoa2001017 Medline

3. H. Zhou, X. Chen, T. Hu, J. Li, H. Song, Y. Liu, P. Wang, D. Liu, J. Yang, E. C. Holmes, A. C. Hughes, Y. Bi, W. Shi, A Novel Bat Coronavirus Closely Related to SARS-CoV2 Contains Natural Insertions at the S1/S2 Cleavage Site of the Spike Protein. Curr. Biol. 30, 2196-2203.e3 (2020). doi:10.1016/i.cub.2020.05.023 Medline

4. C. Drosten, S. Günther, W. Preiser, S. van der Werf, H.-R. Brodt, S. Becker, H. Rabenau, M. Panning, L. Kolesnikova, R. A. M. Fouchier, A. Berger, A.-M. Burguière, J. Cinatl, M. Eickmann, N. Escriou, K. Grywna, S. Kramme, J.-C. Manuguerra, S. Müller, V. Rickerts, M. Stürmer, S. Vieth, H.-D. Klenk, A. D. M. E. Osterhaus, H. Schmitz, H. W. Doerr, Identification of a novel coronavirus in patients with severe acute respiratory syndrome. N. Engl. J. Med. 348, 1967-1976 (2003). doi:10.1056/NEJMoa030747 Medline

5. T. G. Ksiazek, D. Erdman, C. S. Goldsmith, S. R. Zaki, T. Peret, S. Emery, S. Tong, C. Urbani, J. A. Comer, W. Lim, P. E. Rollin, S. F. Dowell, A.-E. Ling, C. D. Humphrey, W.-J. Shieh, J. Guarner, C. D. Paddock, P. Rota, B. Fields, J. DeRisi, J.-Y. Yang, N. Cox, J. M. Hughes, J. W. LeDuc, W. J. Bellini, L. J. Anderson; SARS Working Group, A novel coronavirus associated with severe acute respiratory syndrome. N. Engl. J. Med. 348, 1953-1966 (2003). doi:10.1056/NEJMoa030781 Medline

6. A. C. Walls, Y.-J. Park, M. A. Tortorici, A. Wall, A. T. McGuire, D. Veesler, Structure, Function, and Antigenicity of the SARS-CoV-2 Spike Glycoprotein. Cell 181, 281292.e6 (2020). doi:10.1016/j.cell.2020.02.058 Medline

7. D. Wrapp, N. Wang, K. S. Corbett, J. A. Goldsmith, C.-L. Hsieh, O. Abiona, B. S. Graham, J. S. McLellan, Cryo-EM structure of the 2019-nCoV spike in the prefusion conformation. Science 367, 1260-1263 (2020). 
doi:10.1126/science.abb2507 Medline

8. J. Lan, J. Ge, J. Yu, S. Shan, H. Zhou, S. Fan, Q. Zhang, X. Shi, Q. Wang, L. Zhang, X. Wang, Structure of the SARS-CoV-2 spike receptor-binding domain bound to the ACE2 receptor. Nature 581, 215-220 (2020). doi:10.1038/s41586-020-2180-5 Medline

9. J. Shang, G. Ye, K. Shi, Y. Wan, C. Luo, H. Aihara, Q. Geng, A. Auerbach, F. Li, Structural basis of receptor recognition by SARS-CoV-2. Nature 581, 221-224 (2020). doi:10.1038/s41586-020-2179-y Medline

10. R. Yan, Y. Zhang, Y. Li, L. Xia, Y. Guo, Q. Zhou, Structural basis for the recognition of SARS-CoV-2 by full-length human ACE2. Science 367, 1444-1448 (2020). doi:10.1126/science.abb2762 Medline

11. M. Hoffmann, H. Kleine-Weber, S. Schroeder, N. Krüger, T. Herrler, S. Erichsen, T. S. Schiergens, G. Herrler, N.-H. Wu, A. Nitsche, M. A. Müller, C. Drosten, S. Pöhlmann, SARS-CoV-2 Cell Entry Depends on ACE2 and TMPRSS2 and Is Blocked by a Clinically Proven Protease Inhibitor. Cell 181, 271-280.e8 (2020). doi:10.1016/i.cell.2020.02.052 Medline

12. Q. Wang, Y. Zhang, L. Wu, S. Niu, C. Song, Z. Zhang, G. Lu, C. Qiao, Y. Hu, K.-Y. Yuen, Q. Wang, H. Zhou, J. Yan, J. Qi, Structural and Functional Basis of SARSCoV-2 Entry by Using Human ACE2. Cell 181, 894-904.e9 (2020). doi:10.1016/i.cell.2020.03.045 Medline

13. M. Letko, A. Marzi, V. Munster, Functional assessment of cell entry and receptor usage for SARS-CoV-2 and other lineage B betacoronaviruses. Nat. Microbiol. 5 562-569 (2020). doi:10.1038/s41564-020-0688-y Medline

14. M. A. Tortorici, D. Veesler, Structural insights into coronavirus entry. Adv. Virus Res. 105, 93-116 (2019). doi:10.1016/bs.aivir.2019.08.002 Medline

15. P. M. Folegatti, K. J. Ewer, P. K. Aley, B. Angus, S. Becker, S. Belij-Rammerstorfer, D. Bellamy, S. Bibi, M. Bittaye, E. A. Clutterbuck, C. Dold, S. N. Faust, A. Finn, A. L. Flaxman, B. Hallis, P. Heath, D. Jenkin, R. Lazarus, R. Makinson, A. M. Minassian, K. M. Pollock, M. Ramasamy, H. Robinson, M. Snape, R. Tarrant, M. Voysey, C. Green, A. D. Douglas, A. V. S. Hill, T. Lambe, S. C. Gilbert, A. J. Pollard, J. Aboagye, K. Adams, A. Ali, E. Allen, J. L. Allison, R. Anslow, E. H. Arbe-Barnes, G. Babbage, K. Baillie, M. Baker, N. Baker, P. Baker, I. Baleanu, J. Ballaminut, E. Barnes, J. Barrett, L. Bates, A. Batten, K. Beadon, R. Beckley, E. Berrie, L. Berry, A. Beveridge, K. R. Bewley, E. M. Bijker, T. Bingham, L. Blackwell, C. L. Blundell, E. Bolam, E. Boland, N. Borthwick, T. Bower, A. Boyd, T. Brenner, P. D. Bright, C. Brown-O'Sullivan, E. Brunt, J. Burbage, S. Burge, K. R. Buttigieg, N. Byard, I. Cabera Puig, A. Calvert, S. Camara, M. Cao, F. Cappuccini, M. Carr, M. W. Carroll, V. Carter, K. Cathie, R. J. Challis, S. Charlton, I. Chelysheva, J.-S. Cho, P. Cicconi, L. Cifuentes, H. Clark, E. Clark, T. Cole, R. Colin-Jones, C. P. Conlon, A. Cook, N. S Coombes, R. Cooper, C. A. Cosgrove, K. Coy, W. E. M. Crocker, C. J. Cunningham, B. E. Damratoski, L. Dando, M. S. Datoo, H. Davies, H. De Graaf, T. Demissie, C. Di Maso, I. Dietrich, T. Dong, F. R. Donnellan, N. Douglas, C. Downing, J. Drake, R. Drake-Brockman, R. E. Drury, S. J. Dunachie, N. J. Edwards, F. D. L. Edwards, C. J. Edwards, S. C. Elias, M. J. Elmore, K. R. W. Emary, M. R. English, S. Fagerbrink, S. Felle, S. Feng, S. Field, C. Fixmer, C. Fletcher, K. J. Ford, J. Fowler, P. Fox, E. Francis, J. Frater, J. Furze, M. Fuskova, E. Galiza, D. Gbesemete, C. Gilbride, K. Godwin, G. Gorini, L. Goulston, C. Grabau, L. Gracie, Z. Gray, L. B. Guthrie, M. Hackett, S. Halwe, E. Hamilton, J. Hamlyn, B. Hanumunthadu, I. Harding, S. A. Harris, A. Harris, D. Harrison, C. Harrison, T. C. Hart, L. Haskell, S. Hawkins, I. Head, J. A. Henry, J. Hill, S. H. C. Hodgson, M. M. Hou, E. Howe, N. Howell, C. Hutlin, S. Ikram, C. Isitt, P. Iveson, S. Jackson, F. Jackson, S. W. James, M. Jenkins, E. Jones, K. Jones, C. E. Jones, B. Jones, R. Kailath, K. Karampatsas, J. Keen, S. Kelly, D. Kelly, D. Kerr, S. Kerridge, L. Khan, U. Khan, A. Killen, J. Kinch, T. B. King, L. King, J. King, L. Kingham-Page, P. Klenerman, F. Knapper, J. C. Knight, D. Knott, S. Koleva, A. Kupke, C. W. Larkworthy, J. P. J. Larwood, A. Laskey, A. M. Lawrie, A. Lee, K. Y. Ngan Lee, E. A. Lees, H. Legge, A. Lelliott, N.-M. Lemm, A. M. Lias, A. Linder, S. Lipworth, X. Liu, S. Liu, R. Lopez Ramon, M. Lwin, F. Mabesa, M. Madhavan, G. Mallett, K. Mansatta, I. Marcal, S. Marinou, E. Marlow, J. L. Marshall, J. Martin, J. McEwan, L. Mclnroy, G. Meddaugh, A. J. Mentzer, N. Mirtorabi, M. Moore, E. Moran, E. Morey, V. Morgan, S. J. Morris, H. Morrison, G. Morshead, R. Morter, Y. F. Mujadidi, J. Muller, T. Munera-Huertas, C. Munro, A. Munro, S. Murphy, V. J. Munster, P. Mweu, A. Noé, F. L. Nugent, E. Nuthall, K. O'Brien, D. O'Connor, B. Oguti, J. L. Oliver, C. Oliveira, P. J. O'Reilly, M. Osborn, P. Osborne, C. Owen, D. Owens, N. Owino, M. Pacurar, K. Parker, H. Parracho, M. PatrickSmith, V. Payne, J. Pearce, Y. Peng, M. P. Peralta Alvarez, J. Perring, K. Pfafferott,
D. Pipini, E. Plested, H. Pluess-Hall, K. Pollock, I. Poulton, L. Presland, S. Provstgaard-Morys, D. Pulido, K. Radia, F. Ramos Lopez, J. Rand, H. Ratcliffe, T. Rawlinson, S. Rhead, A. Riddell, A. J. Ritchie, H. Roberts, J. Robson, S. Roche, C. Rohde, C. S. Rollier, R. Romani, I. Rudiansyah, S. Saich, S. Sajjad, S. Salvador, L. Sanchez Riera, H. Sanders, K. Sanders, S. Sapaun, C. Sayce, E. Schofield, G. Screaton, B. Selby, C. Semple, H. R. Sharpe, I. Shaik, A. Shea, H. Shelton, S. Silk, L. Silva-Reyes, D. T. Skelly, H. Smee, C. C. Smith, D. J. Smith, R. Song, A. J. Spencer, E. Stafford, A. Steele, E. Stefanova, L. Stockdale, A. Szigeti, A. TahiriAlaoui, M. Tait, H. Talbot, R. Tanner, I. J. Taylor, V. Taylor, R. Te Water Naude, N. Thakur, Y. Themistocleous, A. Themistocleous, M. Thomas, T. M. Thomas, A. Thompson, S. Thomson-Hill, J. Tomlins, S. Tonks, J. Towner, N. Tran, J. A. Tree, A. Truby, K. Turkentine, C. Turner, N. Turner, S. Turner, T. Tuthill, M. Ulaszewska, R. Varughese, N. Van Doremalen, K. Veighey, M. K. Verheul, I. Vichos, E. Vitale, L. Walker, M. E. E. Watson, B. Welham, J. Wheat, C. White, R. White, A. T. Worth, D. Wright, S. Wright, X. L. Yao, Y. Yau; Oxford COVID Vaccine Trial Group, Safety and immunogenicity of the ChAdOx1 nCoV-19 vaccine against SARS-CoV-2: A preliminary report of a phase $1 / 2$, single-blind, randomised controlled trial. Lancet 396, 467-478 (2020). doi:10.1016/S0140-6736(20)31604-4 Medline

16. J. Yu, L. H. Tostanoski, L. Peter, N. B. Mercado, K. McMahan, S. H. Mahrokhian, J. P. Nkolola, J. Liu, Z. Li, A. Chandrashekar, D. R. Martinez, C. Loos, C. Atyeo, S. Fischinger, J. S. Burke, M. D. Slein, Y. Chen, A. Zuiani, F. J. N. Lelis, M. Travers, S. Habibi, L. Pessaint, A. Van Ry, K. Blade, R. Brown, A. Cook, B. Finneyfrock, A. Dodson, E. Teow, J. Velasco, R. Zahn, F. Wegmann, E. A. Bondzie, G. Dagotto, M. S. Gebre, X. He, C. Jacob-Dolan, M. Kirilova, N. Kordana, Z. Lin, L. F. Maxfield, F. Nampanya, R. Nityanandam, J. D. Ventura, H. Wan, Y. Cai, B. Chen, A. G. Schmidt, D. R. Wesemann, R. S. Baric, G. Alter, H. Andersen, M. G. Lewis, D. H. Barouch, DNA vaccine protection against SARS-CoV-2 in rhesus macaques. Science $\mathbf{3 6 9}$, 806-811 (2020). doi:10.1126/science.abc6284 Medline

17. F. C. Zhu, Y.-H. Li, X.-H. Guan, L.-H. Hou, W.-J. Wang, J.-X. Li, S.-P. Wu, B.-S. Wang Z. Wang, L. Wang, S.-Y. Jia, H.-D. Jiang, L. Wang, T. Jiang, Y. Hu, J.-B. Gou, S.-B. Xu, J.-J. Xu, X.-W. Wang, W. Wang, W. Chen, Safety, tolerability, and immunogenicity of a recombinant adenovirus type- 5 vectored COVID-19 vaccine: A dose-escalation, open-label, non-randomised, first-in-human trial. Lancet 395, 1845-1854 (2020). doi:10.1016/S0140-6736(20)31208-3 Medline

18. L. A. Jackson, E. J. Anderson, N. G. Rouphael, P. C. Roberts, M. Makhene, R. N. Coler, M. P. McCullough, J. D. Chappell, M. R. Denison, L. J. Stevens, A. J Pruijssers, A. McDermott, B. Flach, N. A. Doria-Rose, K. S. Corbett, K. M. Morabito, S. O'Dell, S. D. Schmidt, P. A. Swanson 2nd, M. Padilla, J. R. Mascola, K. M. Neuzil, H. Bennett, W. Sun, E. Peters, M. Makowski, J. Albert, K. Cross, W. Buchanan, R. Pikaart-Tautges, J. E. Ledgerwood, B. S. Graham, J. H. Beigel; mRNA-1273 Study Group, An mRNA Vaccine against SARS-CoV-2 - Preliminary Report. N. Engl. J. Med. NEJMoa2022483 (2020). doi:10.1056/NEJMoa2022483 Medline

19. U. Sahin et al., Concurrent human antibody and $T_{H} 1$ type $T$-cell responses elicited by a COVID-19 RNA vaccine. medRxiv 2020.2007.2017.20140533 [Preprint]. (20 July 2020). https://doi.org/10.1101/2020.07.17.20140533.

20. M. J. Mulligan et al., Phase 1/2 Study to Describe the Safety and Immunogenicity of a COVID-19 RNA Vaccine Candidate (BNT162b1) in Adults 18 to 55 Years of Age: Interim Report. medRxiv 2020.2006.2030.20142570 [Preprint]. (1 July 2020). https://doi.org/10.1101/2020.06.30.20142570.

21. D. Pinto, Y.-J. Park, M. Beltramello, A. C. Walls, M. A. Tortorici, S. Bianchi, S. Jaconi, K. Culap, F. Zatta, A. De Marco, A. Peter, B. Guarino, R. Spreafico, E. Cameroni, J. B. Case, R. E. Chen, C. Havenar-Daughton, G. Snell, A. Telenti, H. W. Virgin, A. Lanzavecchia, M. S. Diamond, K. Fink, D. Veesler, D. Corti, Cross-neutralization of SARS-CoV-2 by a human monoclonal SARS-CoV antibody. Nature 583, 290-295 (2020). doi:10.1038/s41586-020-2349-y Medline

22. C. O. Barnes, A. P. West Jr., K. E. Huey-Tubman, M. A. G. Hoffmann, N. G. Sharaf, P. R. Hoffman, N. Koranda, H. B. Gristick, C. Gaebler, F. Muecksch, J. C. C. Lorenzi, S. Finkin, T. Hägglöf, A. Hurley, K. G. Millard, Y. Weisblum, F. Schmidt, T. Hatziioannou, P. D. Bieniasz, M. Caskey, D. F. Robbiani, M. C. Nussenzweig, P. J. Bjorkman, Structures of Human Antibodies Bound to SARS-CoV-2 Spike Reveal Common Epitopes and Recurrent Features of Antibodies. Cell 182, 828-842.e16 (2020). doi:10.1016/i.cell.2020.06.025 Medline

23. D. F. Robbiani, C. Gaebler, F. Muecksch, J. C. C. Lorenzi, Z. Wang, A. Cho, M. Agudelo, C. O. Barnes, A. Gazumyan, S. Finkin, T. Hägglöf, T. Y. Oliveira, C. Viant, A. Hurley, H.-H. Hoffmann, K. G. Millard, R. G. Kost, M. Cipolla, K. Gordon, F. 
Bianchini, S. T. Chen, V. Ramos, R. Patel, J. Dizon, I. Shimeliovich, P. Mendoza, H. Hartweger, L. Nogueira, M. Pack, J. Horowitz, F. Schmidt, Y. Weisblum, E. Michailidis, A. W. Ashbrook, E. Waltari, J. E. Pak, K. E. Huey-Tubman, N. Koranda, P. R. Hoffman, A. P. West Jr., C. M. Rice, T. Hatziioannou, P. J. Bjorkman, P. D. Bieniasz, M. Caskey, M. C. Nussenzweig, Convergent antibody responses to SARS-CoV-2 in convalescent individuals. Nature 584, 437-442 (2020). doi:10.1038/s41586-020-2456-9 Medline

24. C. Wang et al., A human monoclonal antibody blocking SARS-CoV-2 infection. bioRxiv, 2020.2003.2011.987958 [Preprint]. (12 March 2020). https://doi.org/10.1101/2020.03.11.987958.

25. Y. Wu, F. Wang, C. Shen, W. Peng, D. Li, C. Zhao, Z. Li, S. Li, Y. Bi, Y. Yang, Y. Gong, H. Xiao, Z. Fan, S. Tan, G. Wu, W. Tan, X. Lu, C. Fan, Q. Wang, Y. Liu, C. Zhang, J. Qi, G. F. Gao, F. Gao, L. Liu, A noncompeting pair of human neutralizing antibodies block COVID-19 virus binding to its receptor ACE2. Science 368, 1274-1278 (2020). doi:10.1126/science.abc2241 Medline

26. P. J. M. Brouwer, T. G. Caniels, K. van der Straten, J. L. Snitselaar, Y. Aldon, S. Bangaru, J. L. Torres, N. M. A. Okba, M. Claireaux, G. Kerster, A. E. H. Bentlage, M. M. van Haaren, D. Guerra, J. A. Burger, E. E. Schermer, K. D. Verheul, N. van der Velde, A. van der Kooi, J. van Schooten, M. J. van Breemen, T. P. L. Bijl, K. Sliepen, A. Aartse, R. Derking, I. Bontjer, N. A. Kootstra, W. J. Wiersinga, G. Vidarsson, B. L. Haagmans, A. B. Ward, G. J. de Bree, R. W. Sanders, M. J. van Gils, Potent neutralizing antibodies from COVID-19 patients define multiple targets of vulnerability. Science 369, 643-650 (2020). doi:10.1126/science.abc5902 Medline

27. E. Seydoux et al., Characterization of neutralizing antibodies from a SARS-CoV-2 infected individual. bioRxiv 2020.2005.2012.091298 [Preprint]. (12 May 2020). https://doi.org/10.1101/2020.05.12.091298.

28. L. Piccoli et al., Mapping neutralizing and immunodominant sites on the SARSCoV-2 spike receptorbinding domain by structure-guided high-resolution serology.Cell 10.1016/j.cell.2020.09.037 (2020). doi:10.1016/i.cell.2020.09.037

29. W. B. Alsoussi, J. S. Turner, J. B. Case, H. Zhao, A. J. Schmitz, J. O. Zhou, R. E. Chen, T. Lei, A. A. Rizk, K. M. McIntire, E. S. Winkler, J. M. Fox, N. M. Kafai, L. B. Thackray, A. O. Hassan, F. Amanat, F. Krammer, C. T. Watson, S. H. Kleinstein, D. H. Fremont, M. S. Diamond, A. H. Ellebedy, A Potently Neutralizing Antibody Protects Mice against SARS-CoV-2 Infection. J. Immunol. 205, 915-922 (2020). doi:10.4049/iimmunol.2000583 Medline

30. T. F. Rogers, F. Zhao, D. Huang, N. Beutler, A. Burns, W. T. He, O. Limbo, C. Smith, G. Song, J. Woehl, L. Yang, R. K. Abbott, S. Callaghan, E. Garcia, J. Hurtado, M. Parren, L. Peng, S. Ramirez, J. Ricketts, M. J. Ricciardi, S. A. Rawlings, N. C. Wu, M. Yuan, D. M. Smith, D. Nemazee, J. R. Teijaro, J. E. Voss, I. A. Wilson, R. Andrabi, B. Briney, E. Landais, D. Sok, J. G. Jardine, D. R. Burton, Isolation of potent SARSCoV-2 neutralizing antibodies and protection from disease in a small animal model. Science 369, 956-963 (2020). doi:10.1126/science.abc7520 Medline

31. S. J. Zost, P. Gilchuk, J. B. Case, E. Binshtein, R. E. Chen, J. P. Nkolola, A. Schäfer J. X. Reidy, A. Trivette, R. S. Nargi, R. E. Sutton, N. Suryadevara, D. R. Martinez, L. E. Williamson, E. C. Chen, T. Jones, S. Day, L. Myers, A. O. Hassan, N. M. Kafai, E. S. Winkler, J. M. Fox, S. Shrihari, B. K. Mueller, J. Meiler, A. Chandrashekar, N. B. Mercado, J. J. Steinhardt, K. Ren, Y.-M. Loo, N. L. Kallewaard, B. T. McCune, S. P. Keeler, M. J. Holtzman, D. H. Barouch, L. E. Gralinski, R. S. Baric, L. B. Thackray, M. S. Diamond, R. H. Carnahan, J. E. Crowe Jr., Potently neutralizing and protective human antibodies against SARS-CoV-2. Nature 584, 443-449 (2020). doi:10.1038/s41586-020-2548-6 Medline

32. J. Hansen, A. Baum, K. E. Pascal, V. Russo, S. Giordano, E. Wloga, B. O. Fulton, Y. Yan, K. Koon, K. Patel, K. M. Chung, A. Hermann, E. Ullman, J. Cruz, A. Rafique, T. Huang, J. Fairhurst, C. Libertiny, M. Malbec, W. Y. Lee, R. Welsh, G. Farr, S. Pennington, D. Deshpande, J. Cheng, A. Watty, P. Bouffard, R. Babb, N. Levenkova, C. Chen, B. Zhang, A. Romero Hernandez, K. Saotome, Y. Zhou, M. Franklin, S. Sivapalasingam, D. C. Lye, S. Weston, J. Logue, R. Haupt, M. Frieman, G. Chen, W. Olson, A. J. Murphy, N. Stahl, G. D. Yancopoulos, C. A. Kyratsous, Studies in humanized mice and convalescent humans yield a SARS-CoV-2 antibody cocktail. Science 369, 1010-1014 (2020). doi:10.1126/science.abd0827 Medline

33. R. Shi, C. Shan, X. Duan, Z. Chen, P. Liu, J. Song, T. Song, X. Bi, C. Han, L. Wu, G. Gao, X. Hu, Y. Zhang, Z. Tong, W. Huang, W. J. Liu, G. Wu, B. Zhang, L. Wang, J. Qi, H. Feng, F.-S. Wang, Q. Wang, G. F. Gao, Z. Yuan, J. Yan, A human neutralizing antibody targets the receptor-binding site of SARS-CoV-2. Nature 584, 120-124 (2020). doi:10.1038/s41586-020-2381-y Medline

34. B. Ju, Q. Zhang, J. Ge, R. Wang, J. Sun, X. Ge, J. Yu, S. Shan, B. Zhou, S. Song, X. Tang, J. Yu, J. Lan, J. Yuan, H. Wang, J. Zhao, S. Zhang, Y. Wang, X. Shi, L. Liu, J. Zhao, X. Wang, Z. Zhang, L. Zhang, Human neutralizing antibodies elicited by SARS-CoV-2 infection. Nature 584, 115-119 (2020). doi:10.1038/s41586-0202380-z Medline

35. X. Xie et al., A nanoluciferase SARS-CoV-2 for rapid neutralization testing and screening of anti-infective drugs for COVID-19. bioRxiv 2020.2006.2022.165712 [Preprint]. (23 June 2020). https://doi.org/10.1101/2020.06.22.165712.

36. J. B. Case, P. W. Rothlauf, R. E. Chen, Z. Liu, H. Zhao, A. S. Kim, L.-M. Bloyet, Q. Zeng, S. Tahan, L. Droit, M. X. G. Ilagan, M. A. Tartell, G. Amarasinghe, J. P. Henderson, S. Miersch, M. Ustav, S. Sidhu, H. W. Virgin, D. Wang, S. Ding, D. Corti, E. S. Theel, D. H. Fremont, M. S. Diamond, S. P. J. Whelan, Neutralizing Antibody and Soluble ACE2 Inhibition of a Replication-Competent VSV-SARS-CoV-2 and a Clinical Isolate of SARS-CoV-2. Cell Host Microbe 28, 475-485.e5 (2020). doi:10.1016/i.chom.2020.06.021 Medline

37. A. C. Walls, X. Xiong, Y.-J. Park, M. A. Tortorici, J. Snijder, J. Quispe, E. Cameroni, R. Gopal, M. Dai, A. Lanzavecchia, M. Zambon, F. A. Rey, D. Corti, D. Veesler, Unexpected Receptor Functional Mimicry Elucidates Activation of Coronavirus Fusion. Cell 176, 1026-1039.e15 (2019). doi:10.1016/i.cell.2018.12.028 Medline

38. T. Zhou, Y. Tsybovsky, A. S. Olia, J. Gorman, M. A. Rapp, G. Cerutti, P. S. Katsamba, A. Nazzari, A. Schon, P. D. Wang, J. Bimela, W. Shi, I. T. Teng, B. Zhang, J. C. Boyington, G. Y. Chuang, J. M. Sampson, M. Sastry, T. Stephens, J. Stuckey, S. Wang, R. A. Friesner, D. D. Ho, J. R. Mascola, L. Shapiro, P. D. Kwong, A pHdependent switch mediates conformational masking of SARS-CoV-2 spike. bioRxiv 2020.07.04.187989 (2020). Medline

39. Z. Ke, J. Oton, K. Qu, M. Cortese, V. Zila, L. McKeane, T. Nakane, J. Zivanov, C. J. Neufeldt, B. Cerikan, J. M. Lu, J. Peukes, X. Xiong, H.-G. Kräusslich, S. H. W. Scheres, R. Bartenschlager, J. A. G. Briggs, Structures and distributions of SARSCoV-2 spike proteins on intact virions. Nature (2020). doi:10.1038/s41586-0202665-2 Medline

40. M. McCallum, A. C. Walls, J. E. Bowen, D. Corti, D. Veesler, Structure-guided covalent stabilization of coronavirus spike glycoprotein trimers in the closed conformation. Nat. Struct. Mol. Biol. (2020). doi:10.1038/s41594-020-0483-8 Medline

41. S. Bournazos, T. T. Wang, J. V. Ravetch, The Role and Function of Fcy Receptors on Myeloid Cells. Microbiol. Spectr. 4, 10.1128/microbiolspec.MCHD-0045-2016 (2016). Medline

42. Q. Li, J. Wu, J. Nie, L. Zhang, H. Hao, S. Liu, C. Zhao, Q. Zhang, H. Liu, L. Nie, H. Qin, M. Wang, Q. Lu, X. Li, Q. Sun, J. Liu, L. Zhang, X. Li, W. Huang, Y. Wang, The impact of mutations in SARS-CoV-2 spike on viral infectivity and antigenicity. Cell 182 1284-1294.e9 (2020). doi:10.1016/i.cell.2020.07.012 Medline

43. T. N. Starr, A. J. Greaney, S. K. Hilton, D. Ellis, K. H. D. Crawford, A. S. Dingens, M. J. Navarro, J. E. Bowen, M. A. Tortorici, A. C. Walls, N. P. King, D. Veesler, J. D. Bloom, Deep Mutational Scanning of SARS-CoV-2 Receptor Binding Domain Reveals Constraints on Folding and ACE2 Binding. Cell 182, 1295-1310.e20 (2020). doi:10.1016/i.cell.2020.08.012 Medline

44. R. Boudewijns et al., STAT2 signaling as double-edged sword restricting viral dissemination but driving severe pneumonia in SARS-CoV-2 infected hamsters. bioRxiv 2020.2004.2023.056838 [Preprint]. (2 July 2020). https://doi.org/10.1101/2020.04.23.056838.

45. L. Liu, P. Wang, M. S. Nair, J. Yu, M. Rapp, Q. Wang, Y. Luo, J. F.-W. Chan, V. Sahi, A. Figueroa, X. V. Guo, G. Cerutti, J. Bimela, J. Gorman, T. Zhou, Z. Chen, K.-Y. Yuen, P. D. Kwong, J. G. Sodroski, M. T. Yin, Z. Sheng, Y. Huang, L. Shapiro, D. D. $\mathrm{Ho}$, Potent neutralizing antibodies against multiple epitopes on SARS-CoV-2 spike. Nature 584, 450-456 (2020). doi:10.1038/s41586-020-2571-7 Medline

46. M. Schoof et al., An ultra-potent synthetic nanobody neutralizes SARS-CoV-2 by locking Spike into an inactive conformation. bioRxiv 2020.2008.2008.238469 [Preprint]. (17 August 2020). https://doi.org/10.1101/2020.08.08.238469.

47. C. O. Barnes et al., Structural classification of neutralizing antibodies against the SARS-CoV-2 spike receptor-binding domain suggests vaccine and therapeutic strategies. bioRxiv 2020.2008.2030.273920 [Preprint] (30 August 2020). https://doi.org/10.1101/2020.08.30.273920

48. X. Brochet, M. P. Lefranc, V. Giudicelli, IMGT/V-QUEST: The highly customized and 
integrated system for IG and TR standardized V-J and V-D-J sequence analysis. Nucleic Acids Res. 36, W503-W508 (2008). doi:10.1093/nar/gkn316 Medline

49. J. Snijder, M. S. Ortego, C. Weidle, A. B. Stuart, M. D. Gray, M. J. McElrath, M. Pancera, D. Veesler, A. T. McGuire, An Antibody Targeting the Fusion Machinery Neutralizes Dual-Tropic Infection and Defines a Site of Vulnerability on EpsteinBarr Virus. Immunity 48, 799-811.e9 (2018). doi:10.1016/i.jmmuni.2018.03.026 Medline

50. G. Fibriansah, S. M. Lok, The development of therapeutic antibodies against dengue virus. Antiviral Res. 128, 7-19 (2016). doi:10.1016/i.antiviral.2016.01.002 Medline

51. W. Dejnirattisai, W. Wongwiwat, S. Supasa, X. Zhang, X. Dai, A. Rouvinski, A. Jumnainsong, C. Edwards, N. T. H. Quyen, T. Duangchinda, J. M. Grimes, W.-Y. Tsai, C.-Y. Lai, W.-K. Wang, P. Malasit, J. Farrar, C. P. Simmons, Z. H. Zhou, F. A. Rey, J. Mongkolsapaya, G. R. Screaton, A new class of highly potent, broadly neutralizing antibodies isolated from viremic patients infected with dengue virus. Nat. Immunol. 16, 170-177 (2015). doi:10.1038/ni.3058 Medline

52. E. N. Gallichotte, T. J. Baric, B. L. Yount Jr., D. G. Widman, A. Durbin, S. Whitehead, R. S. Baric, A. M. de Silva, Human dengue virus serotype 2 neutralizing antibodies target two distinct quaternary epitopes. PLOS Pathog. 14, e1006934 (2018). doi:10.1371/journal.ppat.1006934 Medline

53. D. G. Widman, E. Young, U. Nivarthi, J. A. Swanstrom, S. R. Royal, B. L. Yount, K. Debbink, M. Begley, S. Marcet, A. Durbin, A. M. de Silva, W. B. Messer, R. S. Baric, Transplantation of a quaternary structure neutralizing antibody epitope from dengue virus serotype 3 into serotype 4. Sci. Rep. 7, 17169 (2017). doi:10.1038/s41598-017-17355-5 Medline

54. F. Long, M. Doyle, E. Fernandez, A. S. Miller, T. Klose, M. Sevvana, A. Bryan, E. Davidson, B. J. Doranz, R. J. Kuhn, M. S. Diamond, J. E. Crowe Jr., M. G. Rossmann, Structural basis of a potent human monoclonal antibody against Zika virus targeting a quaternary epitope. Proc. Natl. Acad. Sci. U.S.A. 116, 1591-1596 (2019). doi:10.1073/pnas.1815432116 Medline

55. B. R. West, C. L. Moyer, L. B. King, M. L. Fusco, J. C. Milligan, S. Hui, E. O. Saphire, Structural Basis of Pan-Ebolavirus Neutralization by a Human Antibody against a Conserved, yet Cryptic Epitope. mBio 9, e01674-18 (2018). doi:10.1128/mBio.01674-18 Medline

56. B. Kaufmann, M. R. Vogt, J. Goudsmit, H. A. Holdaway, A. A. Aksyuk, P. R. Chipman, R. J. Kuhn, M. S. Diamond, M. G. Rossmann, Neutralization of West Nile virus by cross-linking of its surface proteins with Fab fragments of the human monoclonal antibody CR4354. Proc. Natl. Acad. Sci. U.S.A. 107, 18950-18955 (2010). doi:10.1073/pnas.1011036107 Medline

57. E. T. Crooks, T. Tong, B. Chakrabarti, K. Narayan, I. S. Georgiev, S. Menis, X. Huang, D. Kulp, K. Osawa, J. Muranaka, G. Stewart-Jones, J. Destefano, S. O'Dell, C. LaBranche, J. E. Robinson, D. C. Montefiori, K. McKee, S. X. Du, N. Doria-Rose, P. D. Kwong, J. R. Mascola, P. Zhu, W. R. Schief, R. T. Wyatt, R. G. Whalen, J. M. Binley, Vaccine-Elicited Tier 2 HIV-1 Neutralizing Antibodies Bind to Quaternary Epitopes Involving Glycan-Deficient Patches Proximal to the CD4 Binding Site. PLOS Pathog. 11, e1004932 (2015). doi:10.1371/journal.ppat.1004932 Medline

58. R. N. Kirchdoerfer, N. Wang, J. Pallesen, D. Wrapp, H. L. Turner, C. A. Cottrell, K. S. Corbett, B. S. Graham, J. S. McLellan, A. B. Ward, Stabilized coronavirus spikes are resistant to conformational changes induced by receptor recognition or proteolysis. Sci. Rep. 8, 15701 (2018). doi:10.1038/s41598-018-34171-7 Medline

59. J. Pallesen, N. Wang, K. S. Corbett, D. Wrapp, R. N. Kirchdoerfer, H. L. Turner, C A. Cottrell, M. M. Becker, L. Wang, W. Shi, W.-P. Kong, E. L. Andres, A. N. Kettenbach, M. R. Denison, J. D. Chappell, B. S. Graham, A. B. Ward, J. S. McLellan, Immunogenicity and structures of a rationally designed prefusion MERS-CoV spike antigen. Proc. Natl. Acad. Sci. U.S.A. 114, E7348-E7357 (2017). doi:10.1073/pnas.1707304114 Medline

60. C. L. Hsieh, J. A. Goldsmith, J. M. Schaub, A. M. DiVenere, H.-C. Kuo, K. Javanmardi, K. C. Le, D. Wrapp, A. G. Lee, Y. Liu, C.-W. Chou, P. O. Byrne, C. K. Hjorth, N. V. Johnson, J. Ludes-Meyers, A. W. Nguyen, J. Park, N. Wang, D. Amengor, J. J. Lavinder, G. C. Ippolito, J. A. Maynard, I. J. Finkelstein, J. S. McLellan, Structure-based design of prefusion-stabilized SARS-CoV-2 spikes. Science 369, 1501-1505 (2020). doi:10.1126/science.abd0826 Medline

61. X. Ou, Y. Liu, X. Lei, P. Li, D. Mi, L. Ren, L. Guo, R. Guo, T. Chen, J. Hu, Z. Xiang, Z. $\mathrm{Mu}, \mathrm{X}$. Chen, J. Chen, K. Hu, Q. Jin, J. Wang, Z. Qian, Characterization of spike glycoprotein of SARS-CoV-2 on virus entry and its immune cross-reactivity with
SARS-CoV. Nat. Commun. 11, 1620 (2020). doi:10.1038/s41467-020-15562-9 Medline

62. M. N. Prichard, C. Shipman Jr., A three-dimensional model to analyze drug-drug interactions. Antiviral Res. 14, 181-205 (1990). doi:10.1016/01663542(90)90001-N Medline

63. C. Suloway, J. Pulokas, D. Fellmann, A. Cheng, F. Guerra, J. Quispe, S. Stagg, C. S. Potter, B. Carragher, Automated molecular microscopy: The new Leginon system. J. Struct. Biol. 151, 41-60 (2005). doi:10.1016/j.jsb.2005.03.010 Medline

64. D. Tegunov, P. Cramer, Real-time cryo-electron microscopy data preprocessing with Warp. Nat. Methods 16, 1146-1152 (2019). doi:10.1038/s41592-019-0580-y Medline

65. A. Punjani, J. L. Rubinstein, D. J. Fleet, M. A. Brubaker, cryoSPARC: Algorithms for rapid unsupervised cryo-EM structure determination. Nat. Methods 14, 290-296 (2017). doi:10.1038/nmeth.4169 Medline

66. J. Zivanov, T. Nakane, B. O. Forsberg, D. Kimanius, W. J. H. Hagen, E. Lindahl, S. H. W. Scheres, New tools for automated high-resolution cryo-EM structure determination in RELION-3. elife 7, e42166 (2018). doi:10.7554/eLife.42166 Medline

67. D. Kimanius, B. O. Forsberg, S. H. Scheres, E. Lindahl, Accelerated cryo-EM structure determination with parallelisation using GPUs in RELION-2. eLife 5, e18722 (2016). doi:10.7554/eLife.18722 Medline

68. A. Punjani, H. Zhang, D. J. Fleet, Non-uniform refinement: Adaptive regularization improves single particle cryo-EM reconstruction. bioRxiv 2019.2012.2015.877092 [Preprint]. (16 December 2019). https://doi.org/10.1101/2019.12.15.877092.

69. J. Zivanov, T. Nakane, S. H. W. Scheres, A Bayesian approach to beam-induced motion correction in cryo-EM single-particle analysis. IUCrJ 6, 5-17 (2019). doi:10.1107/S205225251801463X Medline

70. S. Chen, G. McMullan, A. R. Faruqi, G. N. Murshudov, J. M. Short, S. H. W. Scheres, R. Henderson, High-resolution noise substitution to measure overfitting and validate resolution in 3D structure determination by single particle electron cryomicroscopy. Ultramicroscopy 135, 24-35 (2013). doi:10.1016/j.ultramic.2013.06.004 Medline

71. E. F. Pettersen, T. D. Goddard, C. C. Huang, G. S. Couch, D. M. Greenblatt, E. C. Meng, T. E. Ferrin, UCSF Chimera-A visualization system for exploratory research and analysis. J. Comput. Chem. 25, 1605-1612 (2004). doi:10.1002/jcc.20084 Medline

72. P. Emsley, B. Lohkamp, W. G. Scott, K. Cowtan, Features and development of Coot. Acta Crystallogr. D Biol. Crystallogr. 66, 486-501 (2010). doi:10.1107/S0907444910007493 Medline

73. B. Frenz, S. Rämisch, A. J. Borst, A. C. Walls, J. Adolf-Bryfogle, W. R. Schief, D. Veesler, F. DiMaio, Automatically Fixing Errors in Glycoprotein Structures with Rosetta. Structure 27, 134-139.e3 (2019). doi:10.1016/i.str.2018.09.006 Medline

74. R. Y. Wang, Y. Song, B. A. Barad, Y. Cheng, J. S. Fraser, F. DiMaio, Automated structure refinement of macromolecular assemblies from cryo-EM maps using Rosetta. eLife 5, el7219 (2016). doi:10.7554/eLife.17219 Medline

75. F. DiMaio, Y. Song, X. Li, M. J. Brunner, C. Xu, V. Conticello, E. Egelman, T. Marlovits, Y. Cheng, D. Baker, Atomic-accuracy models from $4.5-\AA$ cryo-electron microscopy data with density-guided iterative local refinement. Nat. Methods 12 , 361-365 (2015). doi:10.1038/nmeth.3286 Medline

76. D. Liebschner, P. V. Afonine, M. L. Baker, G. Bunkóczi, V. B. Chen, T. I. Croll, B. Hintze, L.-W. Hung, S. Jain, A. J. McCoy, N. W. Moriarty, R. D. Oeffner, B. K. Poon, M. G. Prisant, R. J. Read, J. S. Richardson, D. C. Richardson, M. D. Sammito, O. V. Sobolev, D. H. Stockwell, T. C. Terwilliger, A. G. Urzhumtsev, L. L. Videau, C. J. Williams, P. D. Adams, Macromolecular structure determination using X-rays, neutrons and electrons: Recent developments in Phenix. Acta Crystallogr. D Struct. Biol. 75, 861-877 (2019). doi:10.1107/S2059798319011471 Medline

77. V. B. Chen, W. B. Arendall 3rd, J. J. Headd, D. A. Keedy, R. M. Immormino, G. J. Kapral, L. W. Murray, J. S. Richardson, D. C. Richardson, MolProbity: All-atom structure validation for macromolecular crystallography. Acta Crystallogr. D Biol. Crystallogr. 66, 12-21 (2010). doi:10.1107/S0907444909042073 Medline

78. J. Agirre, J. Iglesias-Fernández, C. Rovira, G. J. Davies, K. S. Wilson, K. D. Cowtan, Privateer: Software for the conformational validation of carbohydrate structures. Nat. Struct. Mol. Biol. 22, 833-834 (2015). doi:10.1038/nsmb.3115 Medline

79. T. D. Goddard, C. C. Huang, E. C. Meng, E. F. Pettersen, G. S. Couch, J. H. Morris, T. E. Ferrin, UCSF ChimeraX: Meeting modern challenges in visualization and 
analysis. Protein Sci. 27, 14-25 (2018). doi:10.1002/pro.3235 Medline

80. W. Kabsch, XDS. Acta Crystallogr. D Biol. Crystallogr. 66, 125-132 (2010). doi:10.1107/S0907444909047337 Medline

81. A. J. McCoy, R. W. Grosse-Kunstleve, P. D. Adams, M. D. Winn, L. C. Storoni, R. J. Read, Phaser crystallographic software. J. Appl. Crystallogr. 40, 658-674 (2007). doi:10.1107/S0021889807021206 Medline

82. G. N. Murshudov, P. Skubák, A. A. Lebedev, N. S. Pannu, R. A. Steiner, R. A. Nicholls, M. D. Winn, F. Long, A. A. Vagin, REFMAC5 for the refinement of macromolecular crystal structures. Acta Crystallogr. D Biol. Crystallogr. 67, 355367 (2011). doi:10.1107/S0907444911001314 Medline

83. L. J. Reed, H. Muench, A simple method of estimating fifty per cent endpoints. Am. J. Epidemiol. 27, 493-497 (1938). doi:10.1093/oxfordjournals aje.a118408

\section{ACKNOWLEDGMENTS}

We are grateful to Joel Quispe, Quinton Beedle and Young-Jun Park for assistance with data collection and data analysis. We thank Dr. Alice Covizzi and Dr. Marco Schiuma for their help with patient sample collection. We thank Xin Zhang, Elke Maas, Caroline Dekeyzer and Lindsey Bervoets for help with the hamster experiments. We would like to thank Isaac Hoffman for his help with refinement of the S2E12 Fab crystal structure. We acknowledge the Paul Scherrer Institut, Villigen, Switzerland for provision of synchrotron radiation beamtime at beamline X10SA of the Swiss Light Source and would like to thank Vincent Olieric for assistance with data collection. We gratefully acknowledge the authors, originating and submitting laboratories of the sequences from GISAID's EpiFlu Database on which this research is based. Funding: This study was supported by the National Institute of General Medical Sciences (R01GM120553, D.V.), the National Institute of Allergy and Infectious Diseases (HHSN272201700059C, DV), a Pew Biomedical Scholars Award (D.V.), an Investigators in the Pathogenesis of Infectious Disease Award from the Burroughs Wellcome Fund (D.V.), Fast Grants (D.V.), the University of Washington Arnold and Mabel Beckman cryoEM center, the Pasteur Institute (M.A.T.) the KU Leuven/UZ Leuven COVID-19 Fund (J.N.), the Flanders Fonds voor Wetenschappelijk Onderzoek (FWO, G0G4820N, J.N.) and the Bill and Melinda Gates Foundation (INV-006366, J.N). Author contributions: M.A.T., H.V.D, L.E.R., F.A.L., C.H.D., M.S.D., G.S, D.C., K.F. and D.V. designed experiments. A.R., A.G., M.G. and F.B. collected donors' samples. M.A.T., H.V.D., M.M.C, J.E.B., N.C., S.J., N.S., K.C., M.M. and C.N. expressed and purified proteins. M.B., D.P., A.M., A.D.M, B.G., S.B., F.Z., E.C., E.L, H.T., A.P., J.W., H.K., M.M.R., J.D., J.B.C, R.E.C. and F.B. isolated and characterized mAbs. H.V.D, L.E.R., M.M. and A.M. carried out binding assays. M.A.T. collected cryoEM data. M.A.T. and D.V processed the cryoEM data and built the models. N.C., C.N. and G.S. carried out the crystallographic work. M.A.T., M.B., D.P., H.V.D., L.E.R., M.M., F.A.L., R.S., C.H.D., M.S.P., G.S, D.C., K.F. and D.V. analyzed the data. K.F. and D.V. wrote the manuscript with input from all authors. G.S., M.S.D., H.W.V., D.C., K.F. and D.V. supervised the project. M.S.D. and D.V. acquired funding for this project. Competing interests: All authors except M.A.T, H.V.D, M.M.C., J.E.B. M.S.D. and D.V. are employees of Vir Biotechnology Inc. and may hold shares in Vir Biotechnology Inc. M.S.D. is a consultant for Inbios, Vir Biotechnology, NGM Biopharmaceuticals, and on the Scientific Advisory Boards of Moderna and Immunome. D.V. is a consultant for Vir Biotechnology. The Diamond laboratory has received unrelated funding support in sponsored research agreements from Moderna and Emergent BioSolutions. The Veesler, Diamond and Neyts laboratories have received sponsored research agreements from Vir Biotechnology Inc. H.W.V. is a founder of PierianDx and Casma Therapeutics. Neither company provided funding for this work or is performing related work. Author D.C. is currently listed as an inventor on patent applications which disclose subject matter described in this manuscript. Data and materials availability: The cryoEM maps and atomic coordinates have been deposited to the EMDB and PDB with accession numbers EMD-22668 and PDB 7K4N (S2E12bound SARS-CoV-2 S), EMD-22660 and PDB 7K45 (RBD/S2E12 local refinement), EMD-22659 and PDB 7K43 (S2M11-bound SARS-CoV-2 S). The crystal structure of the S2E12 Fab was deposited to the PDB with accession number PDB 7K3Q. Materials generated in this study will be made available on request, but we may require a completed Materials Transfer Agreement signed with Vir Biotechnology. This work is licensed under a Creative Commons
Attribution 4.0 International (CC BY 4.0) license, which permits unrestricted use, distribution, and reproduction in any medium, provided the original work is properly cited. To view a copy of this license, visit

https://creativecommons.org/licenses/by/4.0/. This license does not apply to figures/photos/artwork or other content included in the article that is credited to a third party; obtain authorization from the rights holder before using such material.

\section{SUPPLEMENTARY MATERIALS}

science.sciencemag.org/cgi/content/full/science.abe3354/DC1

Materials and Methods

Figs. S1 to S9

Tables S1 to S4

References (58-83)

MDAR Reproducibility Checklist

14 August 2020; accepted 21 September 2020

Published online 24 September 2020

10.1126/science.abe3354 
A

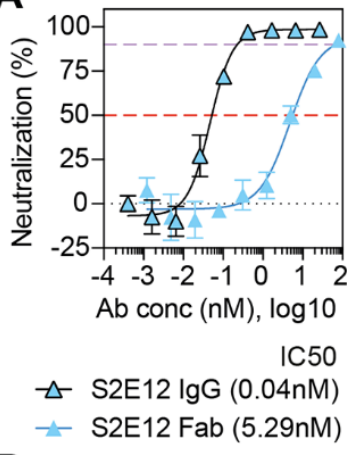

B

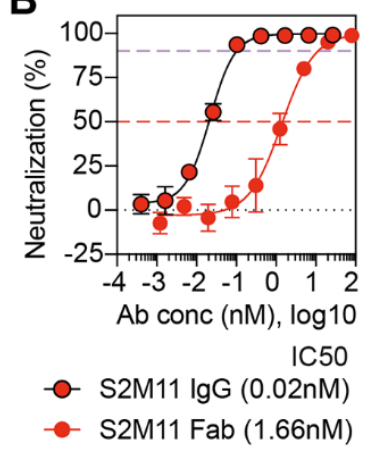

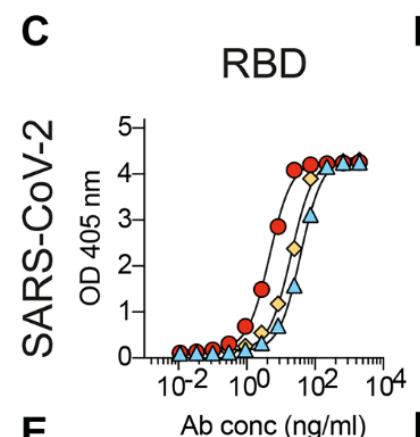

$E$

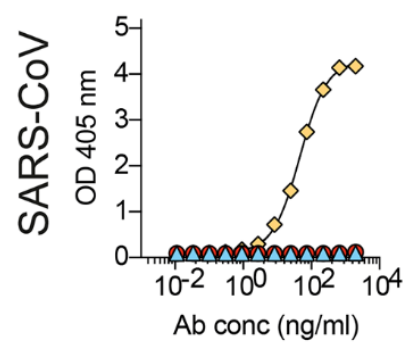

D
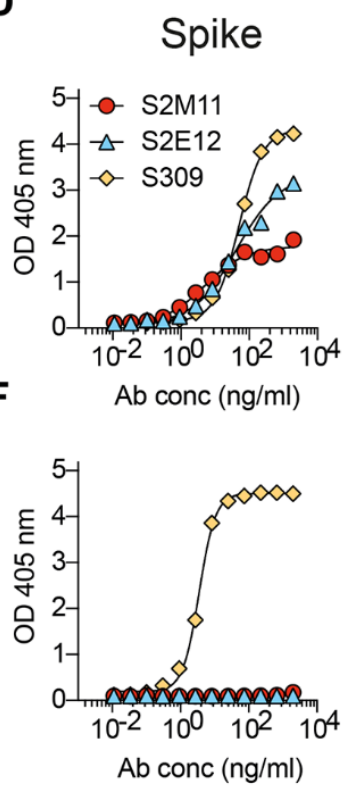

G

Fab binding

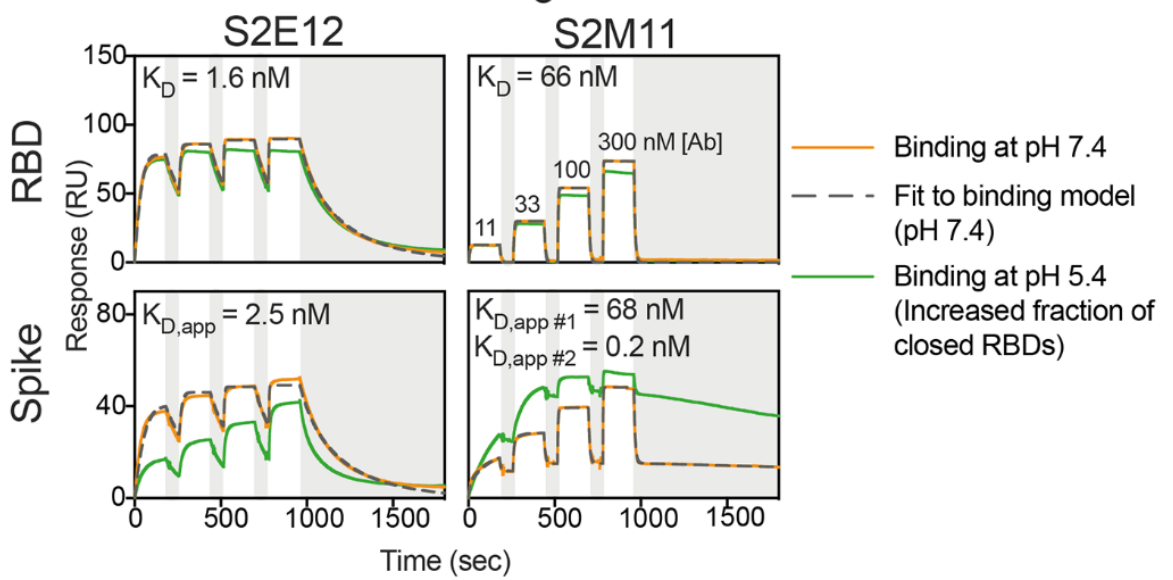

Fig. 1. S2E12 and S2M11 neutralize SARS-CoV-2 ultrapotently via targeting the RBD. (A and B) Neutralization of authentic SARS-CoV-2 (SARSCoV-2-Nluc) by S2E12 (A) and S2M11 (B) IgG or Fab. Symbols are means $\pm S D$ of triplicates. Dotted lines indicate $\mathrm{IC}_{50}$ and $\mathrm{IC}_{90}$ values. Average $I_{50}$ values are indicated in parentheses below the graphs (determined from two independent experiments). ( $\mathrm{C}$ to F) ELISA binding of S2M11 (red), S2E12 (blue) or S309 (yellow) $\mathrm{mAbs}$ to immobilized SARS-CoV2 RBD (C), SARS-CoV-2 S (D), SARS-CoV RBD (E) or SARS-CoV $S(F)$. Symbols show means of duplicates. (G) SPR analysis of S2E12 and S2M11 Fab binding to the SARS-CoV-2 RBD or S ectodomain trimer. Experiments were carried out at $\mathrm{pH} 7.4$ (orange) and $\mathrm{pH} 5.4$ (green) and were repeated twice with similar results (one experiment is shown). The apparent equilibrium dissociation constants $\left(K_{D, \text { app }}\right)$ at pH7.4 are indicated. White and gray stripes indicate association and dissociation phases, respectively. S2M11 binding to $\mathrm{S}$ was fit to two parallel kinetic phases and the resulting $K_{D \text {, app \#1 }}$ and $K_{D}$ app \#2 were interpreted as apparent affinities for open RBDs (tertiary epitope) and closed RBDs (quaternary epitope), respectively. This is supported by the similar binding kinetics and affinity of the faster off-rate phase $\left(K_{D}\right.$, app \#1) with that observed for S2M11 binding to the isolated RBD (cf. table S1 for full fit results). $A b$ conc: $m A b$ concentration. 


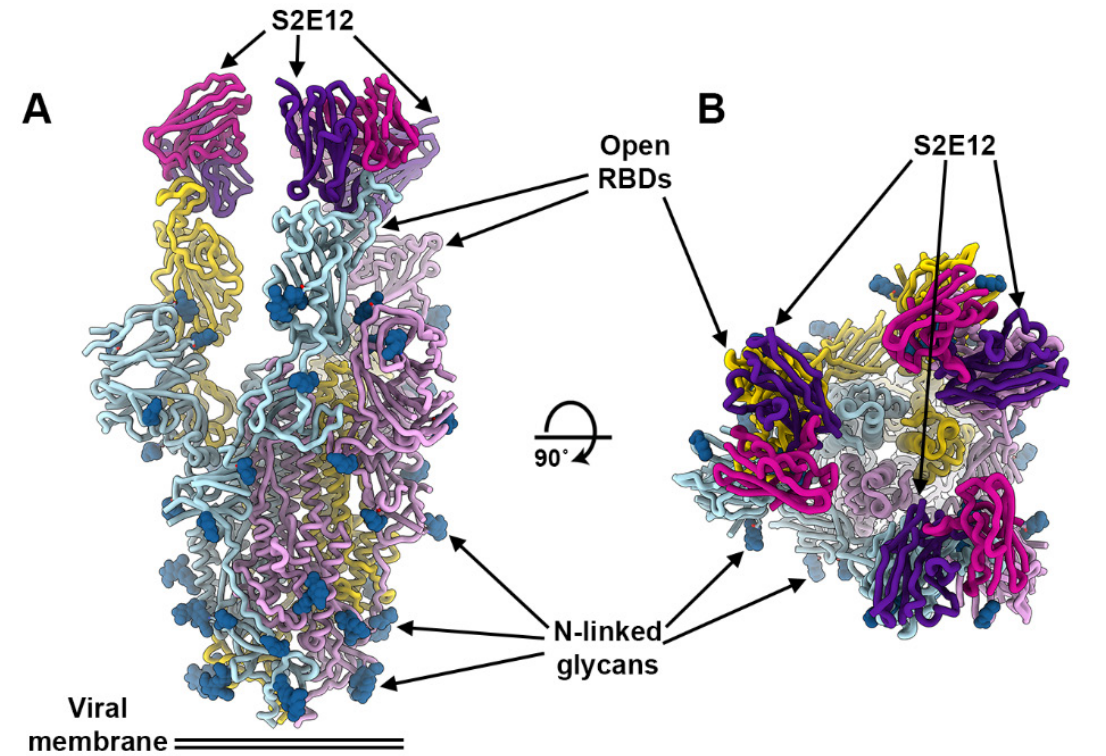

membrane $=$
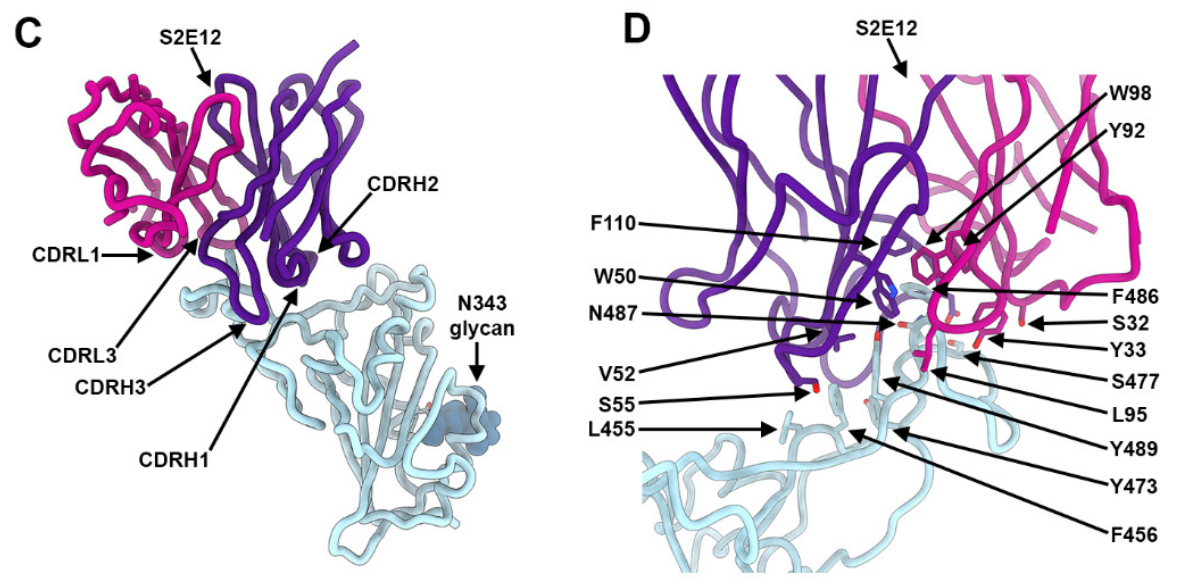

Fig. 2. The S2E12 neutralizing $m A b$ recognizes the SARS-CoV2 RBM. (A and B) CryoEM structure of the prefusion SARSCoV-2 S ectodomain trimer with three S2E12 Fab fragments bound to three open RBDs viewed along two orthogonal orientations. (C) The S2E12 concave paratope recognizes the convex RBM tip. (D) Close-up view showing selected interactions formed between S2E12 and the SARS-CoV-2 RBD. In panels A-D, each SARS-CoV-2 $S$ protomer is colored distinctly (cyan, pink and gold) whereas the S2E12 light and heavy chain variable domains are colored magenta and purple, respectively. $\mathrm{N}$-linked glycans are rendered as blue spheres in panels A-C. 
A

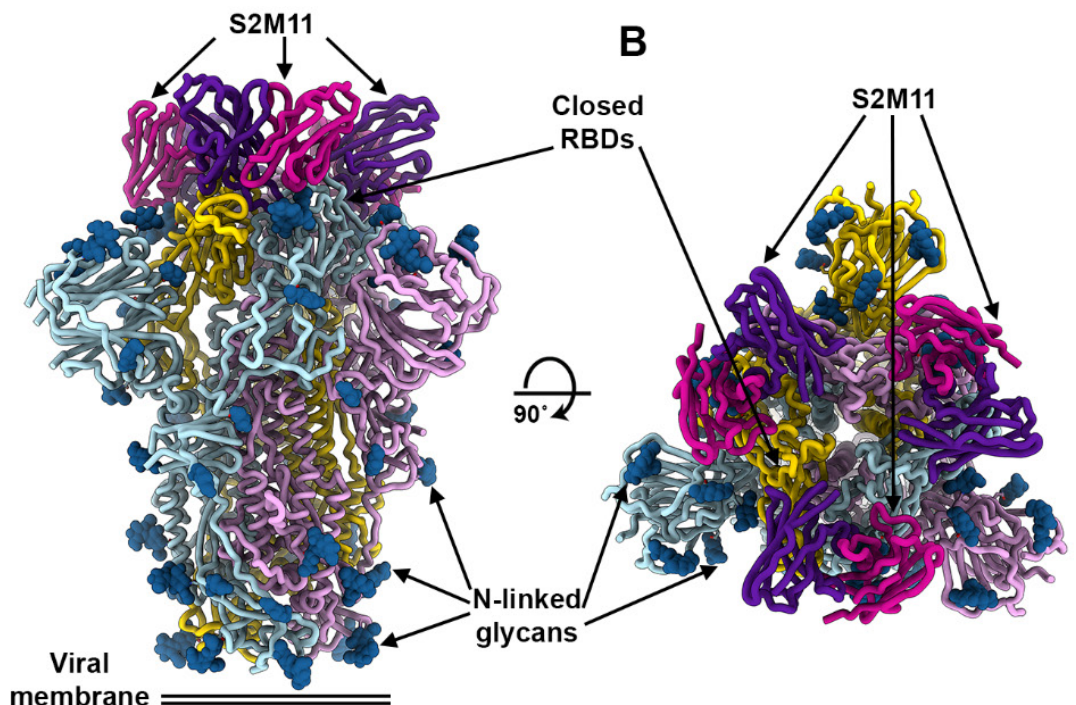

membrane

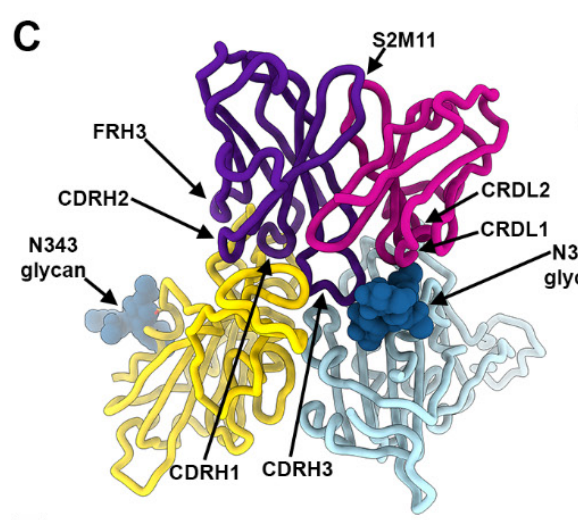

E

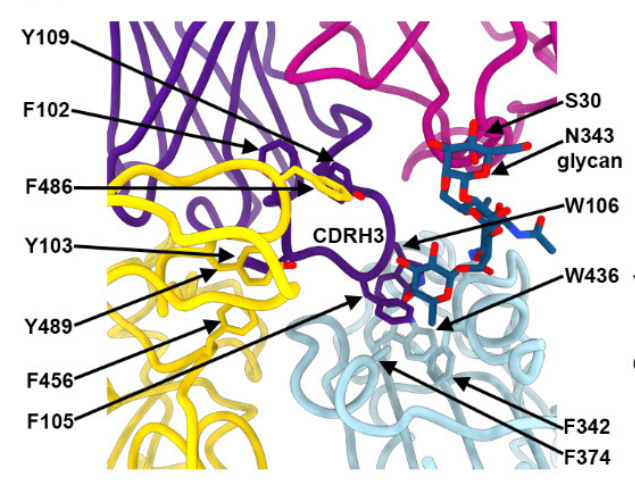

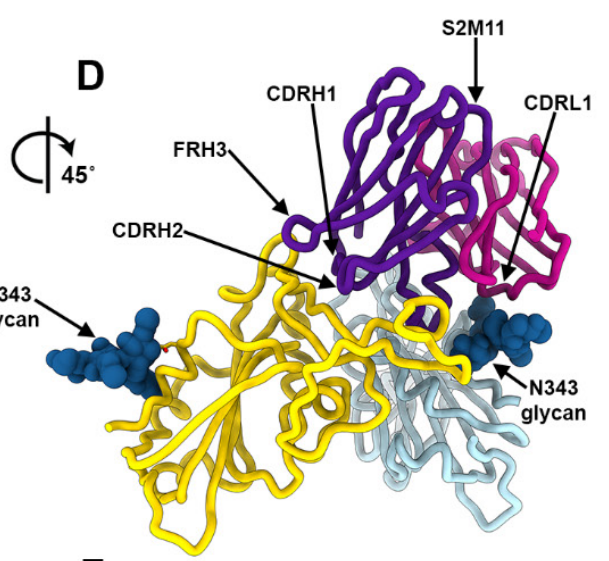

$\mathbf{F}$

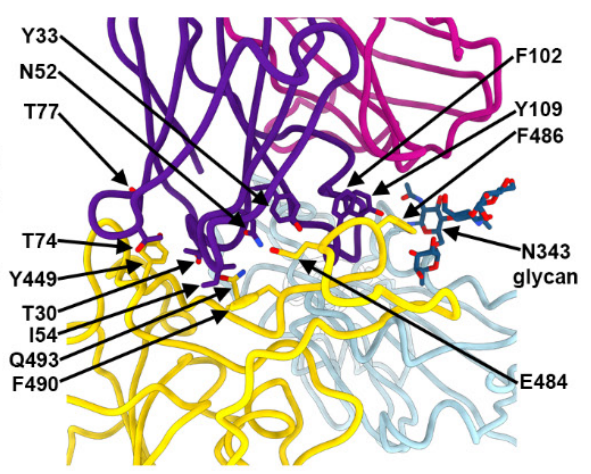

Fig. 3. The S2M11 neutralizing mAb recognizes a quaternary epitope spanning two RBDs and stabilizes $S$ in the closed state. ( $A$ and $B$ ) CryoEM structure of the prefusion SARS-CoV-2 S ectodomain trimer bound to three S2M11 Fab fragments viewed along two orthogonal orientations. ( $C$ and $D$ ) The S2M11 binding pose, which involves a quaternary epitope spanning two neighboring RBDs. $(E$ and $F$ ) Close-up views showing selected interactions formed between S2M11 and the SARSCoV-2 RBDs. In panels A-F, each SARS-CoV-2 $S$ protomer is colored distinctly (cyan, pink and gold) whereas the S2M11 light and heavy chain variable domains are colored magenta and purple, respectively. $\mathrm{N}$-linked glycans are rendered as blue spheres in panels $A-D$ and as sticks in panels E-F. FR: framework 
A

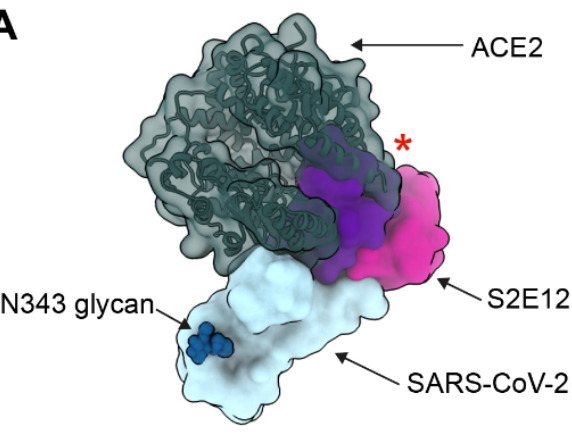

ACE2

C

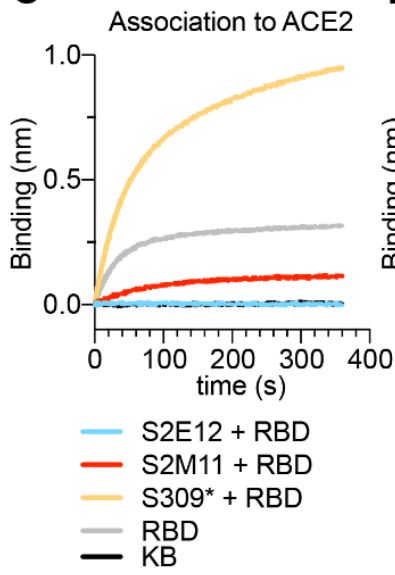

F

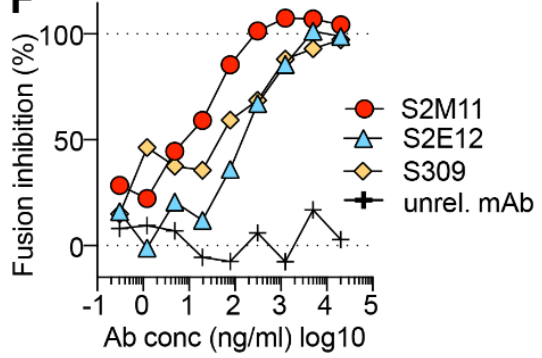

D

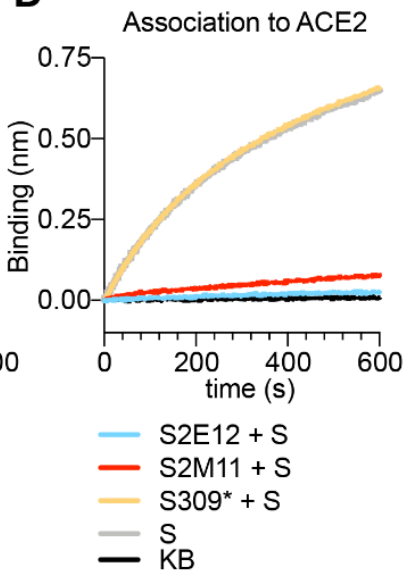

B S

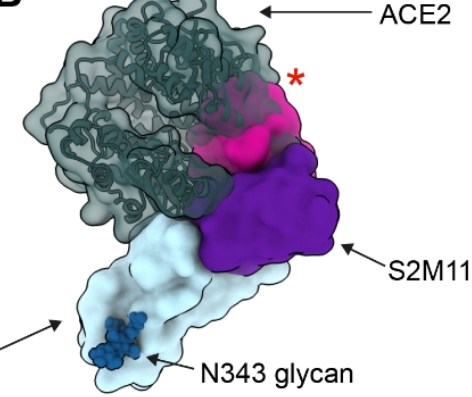

E

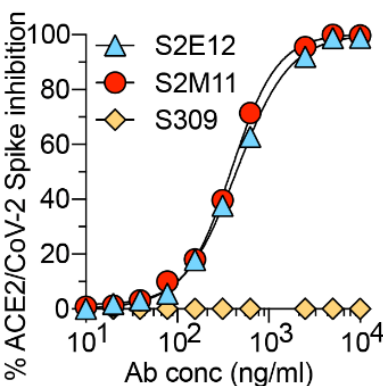

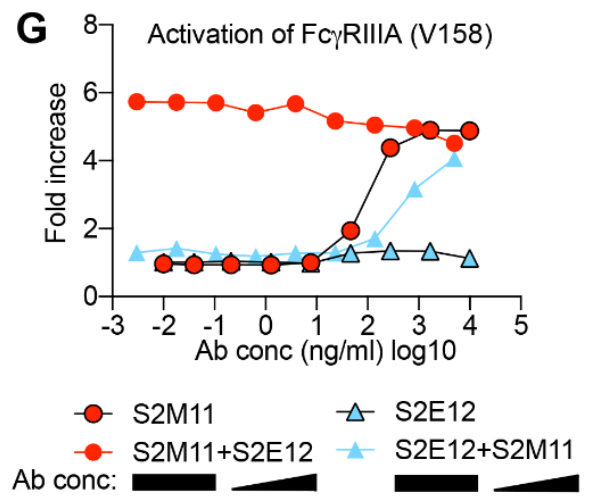
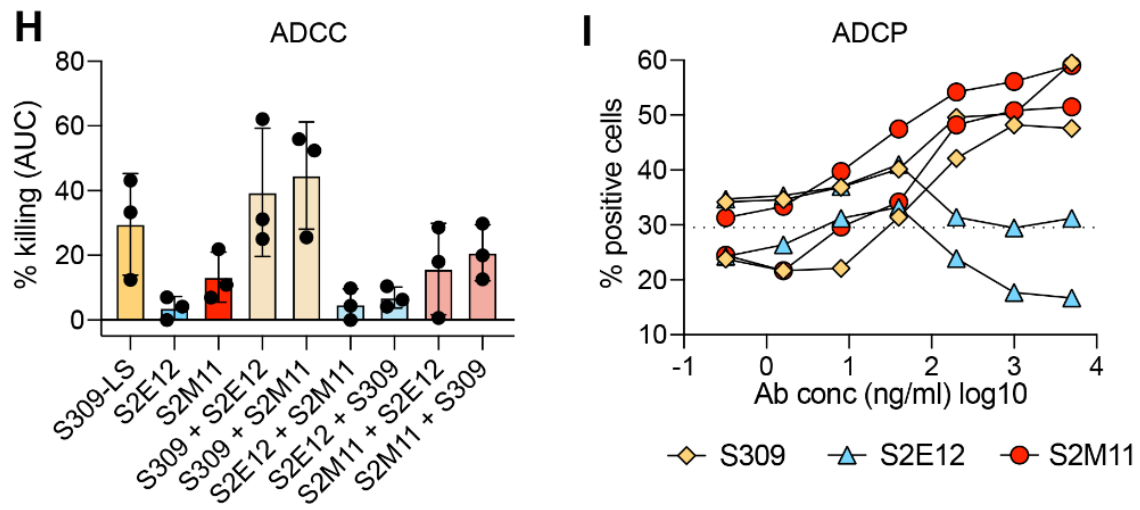
Fig. 4. S2E12 and S2M11 prevent SARS-CoV-2 S attachment to ACE2, inhibit membrane fusion and S2M11 triggers effector functions. (A) S2E12 (purple/pink) and ACE2 (dark green) bind overlapping binding sites on the SARS-CoV-2 RBD (blue). (B) S2M11 (purple/pink) and ACE2 (dark green) bind overlapping binding sites on the SARS-CoV-2 RBD (blue). The red stars indicate steric clashes. (C and D) Binding of the SARS-CoV-2 RBD (C) or S ectodomain trimer (D) alone (grey) or precomplexed with the S2M11 (red), S2E12 (blue) or S309* (yellow) mAbs to the ACE2 ectodomain immobilized at the surface of biosensors analyzed by biolayer interferometry. S309* is an optimized version of the parent S309 mAb (21). KB: kinetic buffer (negative control). (E) Binding of varying concentrations of S2E12 (blue), S2M11 (red) or S309 (yellow) mAbs to full-length S expressed at the surface of $\mathrm{CHO}$ cells in the presence of $20 \mu \mathrm{g} / \mathrm{mL}$ of the ACE2 ectodomain analyzed by flow cytometry (one measurement per condition). (F) Cell-cell fusion inhibition assay with Vero E6 cells transfected with SARS-CoV-2 S and incubated with varying concentrations of S2E12 (blue), S2M11 (red) or S309 (yellow) mAbs and a control mAb. The values are normalized to the percentage of fusion without $m A b$ and to the percentage of fusion of nontransfected cells. (G) FcyRIIla (high affinity variant V158) signaling induced by individual mAbs or mAb cocktails. For $\mathrm{mAb}$ cocktails, the concentration of the constant $\mathrm{mAb}$ was $5 \mu \mathrm{g} / \mathrm{ml}$. The concentration of the diluted $\mathrm{mAb}$ is indicated on the $x$ axis. (H) ADCC using primary NK cells as effectors and SARS-CoV-2 S-expressing CHO cells as targets. The magnitude of NK cells-mediated killing is expressed as the area under the curve (AUC) for each mAb used at concentrations ranging between $0.1 \mathrm{ng} / \mathrm{ml}$ and $20 \mu \mathrm{g} / \mathrm{ml}$. For mAb cocktails, the mAb listed first was kept constant at $5 \mu \mathrm{g} / \mathrm{ml}$. Each symbol represents one donor, data are combined from two individual experiments. See fig. S6E for curves from a representative donor. (I) ADCP using PBMCs as a source of phagocytic cells (monocytes) and PKH67-fluorescently labeled S-expressing $\mathrm{CHO}$ cells as target cells. The y axis indicates \% of monocytes double-positive for anti-CD14 (monocyte) marker and PKH67. The dashed line indicates the signal detected in the presence of target and effector cells but without mAb (baseline). Each line indicates the data for one PBMC donor. Symbols are means of duplicates. Data are from one experiment. Ab conc: mAb concentration. 

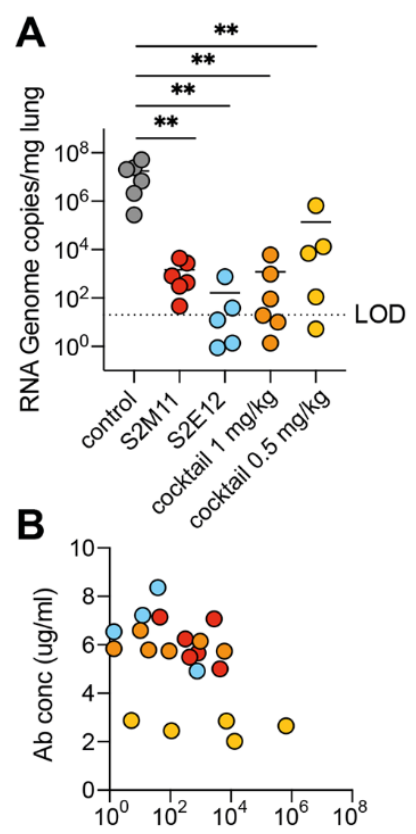

RNA Genome copies/mg lung

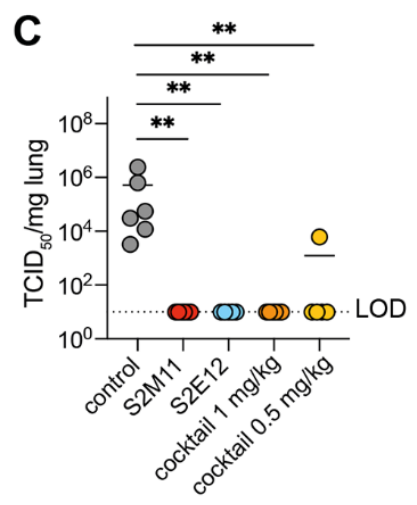

- $\mathrm{S} 2 \mathrm{M} 11,1 \mathrm{mg} / \mathrm{kg}$

- S2E12, $1 \mathrm{mg} / \mathrm{kg}$

- S2M11+S2E12, $1 \mathrm{mg} / \mathrm{kg}$

O S2M11+S2E12, $0.5 \mathrm{mg} / \mathrm{kg}$

- control mAb
Fig. 5. S2E12, S2M11 or cocktails of the two mAbs provide robust in vivo protection against SARS-CoV-2 challenge. Syrian hamsters were injected with the indicated amount of mAb 48 hours before intra-nasal challenge with SARS-CoV-2. (A) Quantification of viral RNA in the lungs 4 days post-infection. (B) The concentration of mAbs measured in the serum before infection (day 0 ) inversely correlates with the viral RNA load in the lung 4 days post infection. (C) Quantification of replicating virus in lung homogenates harvested 4 days post infection using a $\mathrm{TCID}_{50}$ assay. For mAb cocktails, the total dose of an equimolar mixture of both mAbs is indicated. 